ISSN: 0213-2079 - ISSN electrónico: 2386-3889

DOI: https://doi.org/10.14201/shhmo2020422289328

\title{
DESPOBLACIÓN Y REPOBLACIÓN EN LA ESPAÑA MODERNA: CUESTIONES PARA UN DEBATE
}

\section{De-and Re-Population in Early Modern Spain: Questions for a Debate}

\section{Tamar HERZOG}

Universidad de Harvard

therzog@fas.harvard.edu

Fecha de recepción: 06/08/2020

Fecha de aceptación: 18/09/2020

RESUMEN: Se estudia el debate del siglo XVIII en torno de la repoblación de los despoblados con el fin de repensar los criterios barajados en la época. Nos preguntamos cómo se identificaban los despoblados, por qué se los quería reformar y cuál era el papel de la memoria en estos procesos. Igualmente se indaga cómo se entendía la utilidad pública y qué relevancia tienen estos debates en la actualidad.

Palabras claves: despoblado; repoblación; siglo XVIII;reforma territorial; abandono.

ABSTRACT: This text studies $18^{\text {th }}$ century debates regarding the repopulation of depopulated enclaves, with the aim of clarifying the criteria contemporaries used. It asks how contemporaries identified depopulation, why and how they wished to reform depopulated enclaves, whether at stake was the reformation of territory or people, what was the role of memory in these processes, and how public utility was defined. The text ends with questions regarding the relevance of these debates in the present. 
TAMAR HERZOG

DESPOBLACIÓN Y REPOBLACIÓN EN LA ESPAÑA MODERNA: CUESTIONES PARA UN DEBATE

Keywords: depopulation; repopulation; 18th century; territorial reform; abandonment.

En 1784, Domingo Sánchez y otros 20 vecinos de los arrabales de Ciudad Rodrigo pidieron licencia para poblar una dehesa, llamada Martín Hernando, perteneciente al marqués de Algarinejo ${ }^{1}$. Según alegaron, se trataba de un territorio cercano a la ciudad donde solo pastaban animales, pero que podría servir para producir granos y semilla. La repoblación beneficiaría al bien común, favorecería el aumento de la agricultura, la industria y las artes, sin los cuales «no gobiernan las letras ni tienen rigor las armas». La historia que contaban era sencilla: en la diócesis mirobrigense había 150 lugares despoblados «que antes eran muy útiles y productivos en toda línea, y hoy se hallan incultos y reducidos a dehesas de puro pasto y vaqueriles, siendo muchos de ellos (por la espesura de sus montes bajos y altos) madriguera de animales nocivos que de su glorioso y fructífero pasado solo conservaban sus nombres». Que la repoblación era una empresa factible y de mucho provecho ya se sabía por el éxito en la repoblación de Fuente Roble de Abajo, que antes estaba abandonado y ahora era un «jardín» con abundantes frutos.

El abogado del concejo y el párroco apoyaron la petición. Explicaron que, por la falta de tierras, los labradores no casaban a sus hijos y que, por tratarse de una zona limítrofe con Portugal, era necesario asegurar el aumento de la población y que no había mejor método para lograrlo, que establecer pueblos². Sin embargo, el marqués, dueño de la dehesa, se opuso al plan. Por medio de su procurador insistió en su libertad de disponer de su propiedad según y como le pareciera y eligiendo a los arrendatarios que más les gustaran ${ }^{3}$. El marqués también alegó que, por su conocida pobreza, los solicitantes seguramente no estarían en condiciones de pagarle el arrendamiento. El uso de la tierra para pasto no era un mal uso y no había ninguna razón de preferir, a priori y como alegaron los solicitantes, la siembra.

La discusión acaecida en Ciudad Rodrigo en 1785 no era particularmente excepcional. Durante el siglo XVIII a lo largo y ancho de España, otros muchos individuos y grupos también pidieron permiso para instalarse en terrenos que según ellos estaban despoblados, tropezando con la oposición de los propietarios o sus arrendatarios ${ }^{4}$.

1. Petición de Domingo Sánchez y consortes, Ciudad Rodrigo 12.11.1784, Archivo Histórico Nacional (en adelante AHN), consejos 4057, fol. 1r.

2. Informes del párroco Manuel Blanco Arroyo de 29.12.1784 y Francisco Antonio Muñiz, abogado del Ayuntamiento de 3.1.1785, AHN, consejos 4057, fols. 20r-26v.

3. Francisco Antonio Miñon, en nombre del Marqués de Algarinejo y Cardeñosa, AHN, consejos 4057, exp. 16, fols. 42r-53v.

4. Sobre la obsesión con repoblar, véase Herzog, 2010.

Ediciones Universidad de Salamanca / @®@@ Stud. his., H. ${ }^{a}$ mod., 42, n. 2 (2020), pp. 289-328 
La historiografía que estudió estos episodios los utilizó ante todo para analizar los programas que, guiados por el pensamiento ilustrado, se destinaban a asegurar el crecimiento y modernización del país. Esta bibliografía explicaba cómo nacían estos proyectos, dónde, por quién, y cuál habría sido su éxito o fracaso (Cabrillana, 1971; García Zarza, 1978)5. Enfocándose en una historia local (dirigida a reconstruir lo que ocurrió en una población o zona particular), o analizando estas campañas de modo general, esta literatura distinguía entre proyectos dirigidos a repoblar los despoblados y los que se centraron en crear nuevas poblaciones. Enumeraba órdenes regias que mandaban a las autoridades informar al rey cuántos vecinos tenían sus ciudades y villas y qué lugares de su jurisdicción se habían despoblado para que el monarca pueda proveer «los modos más convenientes para la conservación» de los reinos y garantizar el «aumento de la población de estas provincias cuyos lugares se hallan faltos de gente ${ }^{6}$. En el fondo de la cuestión estaba el deseo de contrarrestar la decadencia de España cuya causa, se creía, era la despoblación que producía la falta de desarrollo agrícola e industrial. Como opinó la audiencia de Cáceres en 1796, se trataba de axiomas que deberían de ser evidentes «en un siglo en que las ideas del bien público se hallan más generalmente propagadas que en otros tiempos, mediante las luces e instrucción, que reciba la nación de la experiencia y ejemplo de las extranjeras y de las sabias reglas que continuamente va dando el gobierno para establecer su prosperidad». La audiencia se mostró por tanto sorprendida por la oposición de personas y grupos y la atribuyó a la persistencia de «restos de aquellas máximas erradas y destructoras que, pasando de padres a hijos como por tradición, han retardado hasta nuestros días el establecimiento del aumento y felicidad de la nación» ${ }^{7}$.

En esta ocasión vamos a tomar otro camino. Aprovecharemos el debate en torno de la repoblación para indagar, no tanto sobre lo acaecido en un lugar u otro, ni para juzgar el éxito o fracaso de reformas, sino para repensar los criterios barajados por los contemporáneos. Más allá de la confrontación ya descrita entre acaudalados

5. En 1786 la Real Sociedad Matritense de Amigos del País creó un premio para el mejor ensayo sobre las causas de la despoblación y la falta de cultivo: Archivo de la Real Sociedad Matritense de Amigos del País (en adelante ARSMAP) 85/3. Sus miembros elaboraron varios planes para la población de los despoblados, por ejemplo, el plan de Francisco de Natividad, Madrid, 1.4.1786 ARSMAP 84/4. Rodríguez-Moñino Soriano, 1998, incluye la lista de los legajos del AHN con documentación sobre estas campañas.

6. Vid, por ejemplo, cédula de 22.12.1626 al corregidor de Palencia, Biblioteca Nacional de España (en adelante BNE), mss. 11265/35 y Cédula de Carlos II, impresa, fechada de 14.6.1678 a las autoridades de Castilla la Vieja y Nueva e inserta en «Tomo primero de la colección de varias providencias del consejo desde los años de 1644 hasta el de 1780» BNE, R/23917 n.10.

7. El Acuerdo de la real audiencia de Cáceres, 17.3.1796 en el expediente titulado «Proyecto de población de nominada villa de Balbanera en provincia Extremadura» AHN, consejos 4060, fols. 74v-75r. 
propietarios (y sus renteros) por un lado; labradores pobres sin tierras y sus aliados por otro; entre personas ilustradas y otras reacias a las campañas de repoblación; entre proyectos y su concreta implementación, las discusiones que tuvieron lugar en el siglo XVIII, reproducían una serie de presupuestos y desacuerdos sobre el modo de percibir el territorio y su uso. Si se trataba de aumentar la utilidad de ciertos terrenos, la cuestión sería saber cuáles y cómo. Esta pregunta requería identificar tanto a lo que era preciso remediar, como el modo de hacerlo, por lo que suscitaba debates sobre cómo identificar a los despoblados y en qué consistía la utilidad pública.

\section{IDENTIFICANDO LOS LUGARES A REFORMAR: LOS DESPOBLADOS}

La petición de Domingo Sánchez y consortes para repoblar la dehesa de Martín Hernando invocó la cédula de 28 de noviembre de 1769 y las instrucciones de 23 de mayo de 1770 que mandaron nombrar comisionados para identificar los despoblados y promover su repoblación ${ }^{8}$. Según estas, eran merecedores de reforma todos los lugares donde «se verificase haber habido en algún tiempo pueblo formado con consejo» ${ }^{9}$. A la vista de esto, la discusión en torno a la repoblación de Martín Hernando se centró, inicialmente, en averiguar si la dehesa respondía a esta condición. Según el testimonio de Francisco Antonio Muñiz, abogado del ayuntamiento de Ciudad Rodrigo y asesor de su gobernador, aunque en el presente en Martín Hernando solo había una o dos casas que los guardabosques utilizaban para su abrigo, no faltaban vestigios de haber habido en otros tiempos «una población formal» ${ }^{10}$. En el archivo local se encontraban varios documentos que probaban que este habría sido el caso porque demostraban que entre 1599 y 1706 vivían en la dehesa varios «vecinos contribuyentes». El párroco de la ciudad asintió, testificando que «había tradición ser Martín Hernando cabeza del beneficio e iglesia

8. Informe de Francisco Antonio Muñoz, abogado del Ayuntamiento de 3.1.1785, AHN, consejos 4057, fol. 24r. Vid, igualmente, la historia de esta legislación según narrada por Silverio Mendiuña, procurador del marqués de Algarinejo, en 1816, AHN, consejos 4061, n. 15. La misma también es recogida en la primera parte de la «Real provisión de S.M. y señores del consejo en que se contiene en fuero de población de la Nueva Villa de Encinas del Príncipe... con inserción de las once reglas generales de población establecidas para los despoblados de la propia provincia a consulta del consejo año 1779.» Madrid, Imprenta de Pedro Marín, cuya copia se halla inserta, entre otros, en AHN, consejos 4084, fols. 4r-5v y que está reproducida en la Novísimo Recopilación, Libro 7, título 22, ley 7.

9. La relación entre despoblados y la expirada existencia de una comunidad propiamente dicha, con concejo, vecinos y contribuciones se menciona también en Sánchez Benito, 2013, pp. 329 y 331. El mismo titula a los que no correspondían a ello como «falsos despoblados.»

10. Informe de Francisco Antonio Muñiz, abogado del Ayuntamiento de 3.1.1785, AHN, consejos 4057, exp. 16, fol. 22v.

Ediciones Universidad de Salamanca / @®@@ Stud. his., H. ${ }^{a}$ mod., 42, n. 2 (2020), pp. 289-328 
parroquial». Otros testigos mencionaron que «en 1749 en virtud del real decreto para el establecimiento de la única contribución, se conceptuó la dehesa por si sola en clase de lugar despoblado... y como jamás se ha dudado que en lo antiguo fue lugar y cabeza de beneficio por esto se puso con distinción en esta clase y abajo de este concepto y verídico supuesto» ${ }^{11}$.

Y, sin embargo, el marqués, dueño de la dehesa, estuvo en desacuerdo. Según sostuvo, Martin Hernando nunca había sido un poblado. Se trataba al contrario de un terreno que siempre había servido solo para pasto, que sus ancestros habían comprado a principios del siglo XII con esta misma calidad. El marqués explicó que algunos de sus colonos tal vez habitaban la dehesa de forma cuasi permanente, pero que no se hallaba «en toda su extensión y recinto rastro ni vestigio de despoblado alguno como en ella no ha habido ni se conoció nunca población alguna» ${ }^{12}$. Las únicas estructuras que albergaba Martin Hernando eran dos casas a sus dos extremos que servían para el abrigo y recogida de los guardas y los ganaderos, «de modo que solo eran cabañas y no casas de población». Los archivos, alegó el marqués, apoyaban su versión porque los documentos de compra (de 1136) se referían a una dehesa mientras que otros papeles, de 1589, demostraban que el terreno se arrendó sin habitantes. Martín Hernando, en consecuencia, nunca fue «lugar poblado ni hubo en el vecindario contribuyente, consejo, ni medio concejo con alcalde y otro algún oficial de república». El marqués concluyó argumentando que no había documento alguno «que acredite haber habido en la dehesa población, concejo, feligresía, juez, contribución, ni otra cosa de las que debían concurrir y verificarse para que con verdad pudiera decirse que en ella hay despoblado, de los que según la real cedula y providencia del consejo son y deben ser objeto y materia de la repoblación. Solo hay el abuso y corruptela de llamarla lato modo despoblado a diferencia de los demás lugares que tienen población y como por una especie de idiotismo propio del país según el que vulgar y familiarmente se llaman despoblados los vaqueriles, cabañas y labranzas que en los cuatro reinos de Andalucía se llaman cortijos, pero dicho abuso y corruptela no es suficiente mérito ni prueba para conceptuar a Martín Hernando por despoblado en el riguroso sentido y significado que hablan los decretos del

11. Narciso Francisco Blázquez por los sexmeros y procuradores generales de los cinco campos de Ciudad Rodrigo, AHN, consejos 4057, exp. 16, fols. 51r. El informe del obispo de Ciudad Rodrigo de 2.1.1587 registraba la existencia de dos vecinos en Martín Hernando: González, 1829, p. 233.

12. Francisco Antonio Miñon, en nombre del Marqués de Algarinejo y Cardeñosa, AHN, consejos 4057, exp. 16, fols. 42r-53v, vid especialmente 42v y 45v-48r. La compra del lugar de Martin Hernando en 1135 por Garci López quien se alió con la casa de Chaves y eventualmente la casa de Cerralvo y Villalobos, cuyos descendientes en cierto momento ostentaban el título de «señores de Martín Hernando» se registra en Herrera, 1652, p. 148.

Ediciones Universidad de Salamanca / @®@@ Stud. his., H. ${ }^{a}$ mod., 42, n. 2 (2020), pp. 289-328 
consejo...» ${ }^{13}$. Cualquier otra conclusión convertiría la orden de repoblación en una «facultad para hacer nueva y primitiva fundación» lo que no correspondía a la intención ni del rey ni de su consejo ${ }^{14}$.

Martín Hernando no era el único caso en el que las partes no se pusieron de acuerdo sobre si se trataba o no de un despoblado. Una discusión similar acaeció unos años después, en 1792, cuando varios vecinos también de los arrabales de Ciudad Rodrigo pidieron licencia para repoblar otra dehesa llamada villa de San Martín de Caldillo, perteneciente al marqués de Cerralbo ${ }^{15}$. Según su testimonio, donde al presente solo había una «simple casería», existía en el pasado «una villa poblada» que era cabeza de un beneficio curado. Sin embargo, el arrendatario de la tierra (que contestó por el marqués) lo negó alegando que «la citada dehesa nunca ha tenido vecindario capaz de hacer consejo por sí independiente de otro pueblo» ${ }^{16}$. Tampoco había habido en ella alcaldes y regidores ni demás individuos de justicia, «no habiendo duda de que demás de cuatro siglos a esta parte la dehesa referida no ha sido pueblo con vecindario y consejo». El que se utilizara el término «villa» para referirse a ella nada probaba: «que el título de villa no sea prueba de antigua población cualquiera lo conoce y bastante para ello [el caso de] Peña de Francia que tenemos a la vista y no es, ni jamás ha sido más que un santuario... sin otra población que la del convento de religiosos dominicos, una hospedería para refugio de los devotos... y una ermita esparcida». De todos modos, incluso si San Martín de Caldillo era cabeza de beneficio con silla - lo que el arrendatario negó- esto tampoco implicaba nada. Otros lugares, como el llamado Pedro de Toro, «que es hoy cabeza de beneficio cuyo vecindario no sé que llegue a siete familias de continua residencia y se mantiene sin alcaldes, regidores, procuradores, diputados ni alguna forma de concejo» tampoco lo era, por lo que «veremos que cabe muy bien ser cabeza de beneficio con silla e interés de las tercias reales la mencionada dehesa y no haber tenido la población que se requiere para proceder a repoblarla». Además, «no hay monumento, ni documento alguno, ni antiguo ni moderno, por donde pueda inferirse que la dicha dehesa fuese o hubiese sido en algún tiempo lugar poblado en forma con vecindario, justicia y consejo». En consecuencia, la dehesa de Villa

13. Francisco Antonio Miñon, en nombre del Marqués de Algarinejo y Cardeñosa, AHN, consejos 4057, exp. 16, fol. 47r.

14. Ídem, 48r.

15. Petición de los vecinos del arrabal de San Francisco extramuros de Ciudad Rodrigo a la Junta de Población, 8.9.1792 en «Expediente de repoblación dehesa titulada de San Miguel de Caldillo (Ciudad Rodrigo) del marqués de Cerralbo y oposición de Vicente Bello, vecino de la villa de Palacios Rubio su arrendador, 1792» AHN, consejos 4090.

16. La versión de Vicente Bello está recogida en el poder que otorgó, Palacios Rubios 8.5.1794, y sus varias peticiones, en «Expediente de repoblación dehesa titulada de San Miguel de Caldillo (Ciudad Rodrigo) del marqués de Cerralbo y oposición de Vicente Bello, vecino de la villa de Palacios Rubios su arrendador, 1792» AHN, consejos 4090, fols. 7r-8r, 9r, 11v-12r y 13v.

Ediciones Universidad de Salamanca / @®@@ Stud. his., H. ${ }^{a}$ mod., 42, n. 2 (2020), pp. 289-328 
San Martín de Caldillo no podía estar incluida en la orden de repoblación, que solo ordenaba «restituir a población lo que fueron antiguamente lugares poblados con vecindario, justicia y consejo sin entenderse a conceder la facultar para la erección de nuevas poblaciones donde no las hubo en lo antiguo».

Tres años después, en 1795, el promotor de otra repoblación cerca de Cáceres se involucró en una discusión similar. Buscando acreditar que el territorio donde deseaba asentarse era un verdadero despoblado argumentó que por «noticias» se sabía que, en un pasado, cuyas fechas precisas él no podía identificar, había tenido una población llamada Valdecasa cuya parroquia, actualmente arruinada, fue aneja al lugar de Malpartida, a donde fueron a parar en 1785 sus vasos sagrados. En los archivos, alegó, había constancia de por lo menos una partida de matrimonio celebrado en 1732 entre dos vecinos del lugar ${ }^{17}$. Otros indicios de la antigua población se encontraban en los libros del concejo de Cáceres, que incluían la copia de un privilegio dado por el ayuntamiento en 1429 a los que fueran a poblar la aldea de Aliseda «quemada y robada y despoblada por la guerra que nuestro señor el rey ha habido en el reino de Portugal». Y, a pesar de todas estas pruebas, la parte contraria insistió que no se trataba de un verdadero despoblado. Los vestigios que se observaban en la dehesa no eran más que simples «casas de recogimiento que había para las labranzas de dichos terrenos» y los «lindes con que estaban divididas» las que fueron abandonadas «con motivo de las guerras y contratiempos» ${ }^{18}$.

En 1798, los que pidieron repoblar un lugar llamado Fuenlabrada también intentaron demonstrar que se trataba de un verdadero despoblado. Explicaron que su antigua población era evidente y se podía comprobar «por los surcos y vestigios perceptibles que se manifiestan por la mayor parte de aquel terreno donde hubo iglesia... aunque muy deteriorada en el presente». También habían «algunas casas vivas y permanentes y muchas ya arruinadas ... y partidas de bautismo» por lo que «se viene en conocimiento de haber sido de mucha población según se evidencia de los antiguos libros que se conservan en Cerralbo» ${ }^{19}$.

17. Petición de Cayo Joseph López, vecino de la villa de Zafra en 1795, el certificado del cura de Malpartida y la fe del escribano Antonio Manuel Olivaros de 8.11.1794 en el expediente titulado "Marqués de la Isla, vecino de Cáceres pide porción de tierra...", AHN, consejos 4060 , fols. 2r-v y $5 \mathrm{r}$ y pieza 15 , fol. 1r. Malpatida (pero no Valdecasa) está mencionada en el Nomenclátor, 1789 , p. 405.

18. El informe de los individuos de la junta municipal de propios y arbitrios de Cáceres, 14.4.1795 en el expediente titulado «Proyecto de población de nominada villa de Balbanera en provincia Extremadura» AHN, consejos 4060, fol. 40r.

19. Poder dado a Manuel Rodríguez por Simón Patiño y consortes, vecinos de Cerralbo, 23.9.1798 en el expediente titulado «Manuel Rodríguez sexmero y procurador sindico general tierra de Ciudad Rodrigo sobre que la junta de repoblación de ella lleve a efecto la de las dehesas o despoblado de Ituero, 1798» AHN, consejos 4061, n.2. El mismo expediente incluye otro poder al mismo por varios vecinos de Olmedo que, hablando del despoblado de Ituero

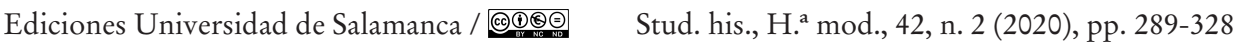


En 1817, al pedir avecindarse en Cejinas según las «reglas y privilegios de repoblación» varios vecinos de Benavente (Zamora) insistieron así mismo de que se trataba de un despoblado: «aunque no existen vestigios claros de haber habido allí población en lo antiguo se infiere que la tuvo por el hecho de haber en el día un beneficio curado titulado de dicho despoblado... cuyo poseedor cobra los diezmos ${ }^{20}$. Además, de un pleito sobre mancomunidad de pastos fechado en 1553 se podría deducir que el lugar estaba poblado y lo mismo se podría inferir de que había tenido párroco.

En muchos casos, la pregunta de si ciertos lugares habían sido poblados y cuáles eran las pruebas para demostrarlo, era legítima; en otros cabe suponer que solo se invocaba para dilatar los procedimientos. Tal vez a esto se refería en 1784 el fiscal del Consejo de Castilla cuando se mostró bastante impaciente con la continua discusión sobre la verdadera condición de Arauzo (Salamanca) ${ }^{21}$. Se sabía, dijo, que había sido una villa, cuyo nombre conservaba siempre, de unos 300 vecinos y porque «retiene algunos vestigios, como es su rollo, un molino corriente, caño, fuente, y sobre todo iglesia con pila bautismal, donde se dice misa los días festivos y un beneficiado que reside en la villa de Ventosa (del Río Almar), de quien es anejo, y administra todos los sacramentos a los que viven en las tres casas que hay». A vista de todo esto, «no podrá ya dudarse... que Arauzo es verdaderamente despoblado cuando mantuvo hasta finales del siglo pasado vecindad y feligresía».

Es cierto que las partes tomaban una $\mathrm{u}$ otra postura siguiendo sus propios intereses, pero las discusiones en torno a la identificación de los despoblados ponían de manifiesto que los contemporáneos intentaban distinguir entre lugares deshabitados y despoblados ${ }^{22}$. Es decir, aunque criticaban todo abandono, fuera el que fuera su razón de ser y aunque insistían en la obligación de luchar contra todo lo que estaba «dolorosamente abandonado» eliminado «tierras baldías, montañosas, incultas y

mencionan igualmente que tiene ruinas de casas e iglesia y se sabe fue labrado en «lo antiguo» por los surcos que hay.

20. El procurador de Matías Cascón y otros vecinos de Benavente, AHN, consejos 4047 n.14, fol. 3v. Todavía por 2006, el ayuntamiento de Benavente buscaba subastar parcelas en la dehesa de Cejinas: recuperado de https://www.laopiniondezamora.es/benavente/1624/subastancuatro-parcelas-municipalesen-dehesa-cejinas/165467.html. El mapa actual de la dehesa es disponible en https://cartographic.info/espana/map.php?id=967514. Vid igualmente, Ramón Antonio Bustamante, procurador sindico villa de Benavente, 22.8.1817, AHN, consejos 4047 n.14, fol. 15v y el fiscal del consejo, AHN, consejos 4047 n.14, fol. 25r.

21. Vista fiscal, vista en el consejo el 14.12.1784, ANH, consejos 4062, fols. 75r-82r, en fols. $77 \mathrm{v}$. Un acuerdo de 1423 identificaba a Arauzo como aldea próxima pero no perteneciente a Alba de Tormes: Monsalvo Antón, 1988, p. 64 nota 6. La aldea también se menciona en la documentación de Alba en 1407: ídem, p. 65.

22. Los historiadores destacaron lo difícil que era definir los despoblados en cuanto objeto de estudio. Vid., por ejemplo, Forteza, 1983 y Reglero de la Fuente, 1998, pp. 185-186.

Ediciones Universidad de Salamanca / @®@@ Stud. his., H. ${ }^{a}$ mod., 42, n. 2 (2020), pp. 289-328 
de ningún provecho» que nadie trabajaba» no obstante, mantenían que había una marcada disimilitud entre la obligación de repoblar los despoblados y la creación de nuevos núcleos ${ }^{23}$.

A veces el abandono que criticaban era total, en otras era relativo en el sentido que se estimaba que el uso del terreno era insuficiente. A esto se refería en 1783 la Real Sociedad Matritense de Amigos del País cuando sus integrantes censuraban la «lastimosa despoblación y destrucción de pueblos», que antes eran opulentos y ahora estaban muy decaídos ${ }^{24}$. Lo mismo hacía en 1780 una «relación de despoblados» Salamantinos cuyo autor identificó una serie de núcleos, enumerando los vecinos que vivían en ellos y cotejando éste con el de los vecinos que podrían albergar ${ }^{25}$. En ambos casos, se contrastaba la situación actual con la situación deseada y se quejaba cuando tierras clasificadas de buenas, no estaban ni pobladas ni trabajadas al nivel que supuestamente merecían. El hecho de identificar a un núcleo como «despoblado» por tanto, no indicaba necesariamente el escueto número de personas, sino podría deberse a que este número era inferior a lo que se creía posible ${ }^{26}$. Además, más allá del número de vecinos y del potencial que había, lo fundamental versaba en la convicción de que los despoblados eran lugares que habían tenido concejo y vecinos, es decir, lugares donde había existido una comunidad no solo de hecho, sino también de derecho, pero donde, actualmente, solo quedaban derechos. A esto volveremos en seguida.

¿Por qué insistir en revitalizar lugares que habían sido abandonados en vez de fundar otros, nuevos? ¿y en qué consistía exactamente el abandono que se quería remediar?

\section{LA MEMORIA DE LO QUE HUBO}

La respuesta más intuitiva a la pregunta de por qué repoblar los despoblados sería que, en su caso, operaba una presunción que su reforma era, por definición, de

23. El término «dolorosamente abandonados» fue mencionado en la petición de establecer una colonia llamada Bernardina, ANH, consejos 4047, n. 11. La cita procede de la petición del monasterio de San Jerónimo del Real, extramuros de la ciudad de Córdoba de 1765, ANH, consejos 4057, fols. 8r-11v.

24. La Real Sociedad Matritense de Amigos del País, circ. 1783, ARSMAP 57/12.

25. Juan P. Salvador de Asprer, «relación de despoblados» 29.1.1780, AHN, consejos 4062. Lo mismo es evidente de la lista de despoblados en el partido de Ciudad Rodrigo, Ciudad Rodrigo, 15.12.1784, incluida en AHN, consejos 4057, exp. 16, fols. 14r-19r. Este uso de «despoblado» para designar un abandono relativo se generalizó, al parecer, a partir del siglo XIV: Forteza, 1983, p. 77.

26. En un despoblado podrían residir tanto una sola persona como 54 habitantes: Heras Santos, 2016, pp. 173-174. 
provecho, pues un sitio que alguna vez fue capaz de sostener una población, podría volver a tenerla. Se trataba de terrenos que ya habían probado su valor y que tenían, por tanto, un potencial conocido. Esta convicción se expresaba en la documentación contemporánea, en la que los actores sostenían que «porque habiéndose conservado lugar y poblándose en aquel terreno en lo antiguo» era evidente que podría subsistir y establecerse de nuevo ${ }^{27}$. Si muchas poblaciones «fueren tan grandes y pobladas, ¿porque no lo han de ser ahora otra vez» mayormente «en un tiempo tan ilustrado como lo es el presente?» ${ }^{28}$.

Para sostener esta idea, era preciso empero que los contemporáneos se centrasen en el hecho de que estos lugares habían estado poblados en cierto momento, y se olvidasen de que habían sido abandonados después. $\mathrm{O}$, imaginasen que la despoblación se debió a una negligencia, incluso a un abandono cuasi criminal, y no a razones que no podían evitarse. Según estas narrativas, las razones del despoblamiento eran las personas y no el lugar. «Ni es de consideración el que se hayan despoblado las poblaciones que en este terreno había, para inferir de que esto lo ocasionó la improporción del sitio para la población» ${ }^{29}$. Obedeciendo a estas imágenes, el fiscal del Consejo de Castilla llegó a afirmar en 1796 que a pesar de su abandono, Extremadura podría haber sido la provincia «más poblada y más rica de España» porque su suelo era «fértil y apto para toda clase de producciones» ${ }^{30}$. Por ello, «si no fuesen conocidas las causas de tan funesta decadencia, se pudiera pensar que la naturaleza hasta ha invertido en ella el orden de sus leyes. Todos los pueblos que gozan de un clima benigno y de un suelo fecundo caminan por necesidad a su prosperidad y mayor aumento, pero por desgracia se nota que, gozando Extremadura de esas calidades, lejos de caminar adelante, va retrocediendo y si la mano poderosa del gobierno no sigue aplicando a los vicios que padece los remedios saludables, volverá precisamente al estado primitivo de las naciones bárbaras que no han llegado a conocer otra industria que la de los pastores».

Para explicar la despoblación sin descalificar el terreno, se recurría a un elenco repetitivo de problemas, que teóricamente habían causado el abandono. El favorito era el de los conflictos entre los vecinos, motivados por los «impulsos por dominar, discordias para lograrlo e impedirlo, el propio interés, pasiones y afectos, la general insensibilidad en orden al bien público, impunidad de los delitos, la desatención a las leyes, y las guerras de parcialidades», todos los cuales «extendieron la pobreza

27. El intendente de Córdoba, el 11.12.1766, AHN, consejos 4057, exp. 2, fol. 17v.

28. La Real Sociedad Matritense de Amigos del País, circ. 1783, ARSMAP 57/12.

29. El intendente de Córdoba, el 11.12.1766, AHN, consejos 4057, exp. 2, fol. 23r.

30. Vista del fiscal Francisco Rodríguez Ledesma y Vera de 19.9.1796 en el expediente titulado «Proyecto de población de nominada villa de Balbanera en provincia Extremadura» AHN, consejos 4060, fol. 126r. 
y la ruina de unas casas a otras y aniquilaron al fin la población» ${ }^{31}$. Igual de popular era culpar a los señores y comendadores, los que «procuraron por todos los medios la despoblación, para que quedando el término en su arbitrio les produjese mayores rentas» ${ }^{32}$. Era «el deseo insaciable de enriquecer sin límites» el «origen de la despoblación de nuestras provincias. Los propietarios de los lugares vieron que los productos de ellos estaban más seguros y serían más fácilmente cobrados en un solo colono rico, que en muchos a quienes las calamidades de los tiempos u otras desgracias inevitables podían reducir a la imposibilidad de satisfacer sus rentas. De aquí es que todos vieron con indiferencia y aun con gusto la deserción de sus lugares y la ruina de sus casas». «Los vestigios de edificios... serán monumentos eternos, que pasarán a nuestra posterioridad el conocimiento de la barbaridad de sus dueños, que para ser ricos parece que se han olvidado de que son hombres, manifestando en su proceder la mayor indiferencia por el bien de sus semejantes» ${ }^{33}$. O se argumentaba que estas personas poderosas acapararon tierras que en realidad eran comunales y las trataban como propias, entre otras cosas, oponiéndose a que los demás se aprovecharan de ellas, o las volvieran a poblar ${ }^{34}$. Incluso se imaginaba la posibilidad de incriminar a quien según se alegaba era responsable de la despoblación por su mal comportamiento y opresión a los vecinos ${ }^{35}$.

La existencia de tierras que estaban yermas «por desidia de aquéllos a los que pertenecen», llegó a ser legalmente acuñada en 1749 cuando, para reducir a una Única Contribución la variedad de imposiciones que pagaban los vasallos (Millones, Alcabala, Cientos, Servicio Ordinario y sus agregados), se fijó una tasa radicalmente distinta para estos terrenos que, en cierto modo, implicaba una multa: mientas que los propietarios de las «tierras yermas por naturaleza» pagaban medio real, los que las tenían yermas «por desidia» pagaban cinco. En ambos casos, se suponía que las

31. Esta era la descripción del abandono, hecho por el autor de una obra satírica escrita en 1781: Gutiérrez de Vega, 1781.

32. Martínez de Irujo. Reflexiones sobre las causas que han ocasionado la despoblación de las dos Castillas, Extremadura y Andalucía y la decadencia de la agricultura, citado por Oliveras Samitier, 1983, p.27. Vid, igualmente, Viñas y Mey, 1941.

33. La junta de repoblación de Salamanca, el 26.1.1788, AHN, consejos 4062, fols. $1 \mathrm{r}$-v. Una visión similar se halla en el informe de Manuel Blanco Arroyo, el beneficiado rector de la parroquia de Manzano de Ciudad Rodrigo al alcalde mayor y corregidor interino, 29.12.1784, AHN, consejos 4057, exp. 16, fol. 21v.

34. La junta de repoblación de Salamanca, el 26.1.1788, AHN, consejos 4062, fols. 51r-51v.

35. El fiscal de su majestad contra Juan de Valderas, alcalde mayor de la villa de Santa María (Zamora) de 1629, Archivo de la Chancillería de Valladolid (en adelante ARCHV), Pl. Civiles, Alonso Rodríguez (OLV) 385/1. Vid, igualmente, Diago Hernando, 1991 que describe algunas de estas dinámicas.

Ediciones Universidad de Salamanca / @®@@ Stud. his., H. ${ }^{a}$ mod., 42, n. 2 (2020), pp. 289-328 
TAMAR HERZOG

DESPOBLACIÓN Y REPOBLACIÓN EN LA ESPAÑA MODERNA: CUESTIONES PARA UN DEBATE

tierras, incluso cuando eran yermas, tenían utilidad. Si no otra, por lo menos para «alguna yerba» ${ }^{36}$.

A pesar de estas imágenes que apuntaban regularmente a la culpabilidad de determinadas personas, imágenes que, a veces, ciertamente correspondían a la realidad, en la mayoría de los casos, los esfuerzos por averiguar cuándo y por qué se abandonaron los lugares, normalmente fracasaron. Los contemporáneos confesaban continuamente que las verdaderas causas de la despoblación eran imposibles de averiguar ${ }^{37}$. Poco se sabía de lo que alguna vez hubo y menos de lo que había ocurrido después. Se llegó a afirmar, por ejemplo, que «el número de vecinos que tuvo se ignora, pero dejase conocer que pudo ser muy corto... No se sabe el estado en que lo dejaron los últimos pobladores... Y menos sabemos de los fueros o privilegios de que gozó la población» ${ }^{38}$. O se mantenía que «de fija memoria no se sabe cuándo se despobló dicho término y solo va puesto testimonio... que en el año 1656 se conservaban en él 25 vecinos entre viudas, huérfanos y mozos, de que parece que habrá que se despobló poco más de un siglo, sin que aparezca ni conste la causal» ${ }^{39}$.

La imprecisión y la falta de información eran generales. Según Gabriel Bayán y consortes, residentes en el valle de Ibor (Cáceres), el lugar de Avellaneda (Talavera) fue despoblado un año atrás «por la penuria de los tiempos y otras circunstancias y

36. Decreto real «para que con arreglo a la instrucción, formularios y Planes, que le acompañan se averiguen los efectos, en que puede fundarse una sola contribución» 10.10.1749, AHN, consejos, lib.1519, n.59 y Fondo contemporáneo-Ministerio de Hacienda, lib. 699, p. 12, recuperado de http://www.mcu.es/archivos/lhe/servlets/VisorServlet.jsp?cod=005637. Vid, igualmente, AHN, Fondo contemporáneo-Ministerio de Hacienda, lib. 8017, n. 1085, pp. 101-102.

37. En 1787, por ejemplo, a propósito de las Nuevas Poblaciones (y no la repoblación de los despoblados), el fracaso de Joseph Rafael González a la hora de refundar una población en un baldío de la villa de Espiel en Sierra Morena fue achacada a que muchos colonos «se enfadaron y aburrieron por las continuas desazones que con sus pleitos y alborotos los castigaba Bartolomé Molina» su vecino. Otros tantos estaban en prisión y el resto abandonó el lugar con el cura: Declaración de Joseph Rafael González, 7.8.1878, AHN, consejos 4058, n. 2, fol. 12r. El informe del subdelegado de las nuevas poblaciones Antonio Cerrón Iván de Vargas de 11.11.1787 sin embargo atestiguaba que las razones eran más bien otras: falta de tierras, pósito, casas e iglesia incomoda: vid su testimonio a fols. 109r, 115v y 120v. Los historiadores han adoptado estas imágenes también: Gracia, 1988, p. 25 y Pita González, 2007, pp. 94-95 y 101. La dificultad de conocer las causas de la despoblación es evidente del informe del corregidor de Toro, estudiado en García Caballero, 1989, pp. 43-47. No era por falta de voluntad: el conde de Campomanes como muchos otros recomendó por ejemplo en 1774 a las sociedades económicas de amigos del país averiguar las causas de la repoblación: García Zarza, 1978, p. 15.

38. José García Huerte, alcalde mayor de Benavente, 1.10.1817, AHN, consejos 4047, n. 14 , fol. $17 \mathrm{v}-18 \mathrm{r}$.

39. Informe del alcalde de crimen de la Chancillería de Valladolid, Arévalo 30.8.1767, en el expediente titulado «Priora y convento de S. Agustin de Nuestra Señora...pide repoblar el lugar de Astudillo» AHN, consejos 4086, fol. 68r.

Ediciones Universidad de Salamanca / @®@@ Stud. his., H. ${ }^{a}$ mod., 42, n. 2 (2020), pp. 289-328 
el quitar el cura propio la residencia de teniente y hasta la misa» ${ }^{40}$. Según el primer informe de Francisco de la Rúa y Quiñones, alcalde mayor que fue de Talavera, la despoblación no obstante había tenido lugar mucho antes, en algún momento del siglo anterior y por otra razón: el maestro que gobernó la fábrica de hierro y otros artífices se hicieron «sospechosos del delito de difidencia»y, temerosos del castigo, abandonaron el lugar ${ }^{41}$. Pero, poco después, el mismo informante cambió su parecer y opinó que la despoblación era más reciente. Originalmente el pueblo tuvo 200 vecinos y era el más opulento del valle, e incluso dieciséis años atrás todavía tenía 30 vecinos, pero actualmente solo había en él 19 casas, un molino, muchas ruinas y una iglesia, que era preciso reparar. Las verdaderas causas de la despoblación, explicó, «no todas eran de fácil averiguación» pero él suponía que la razón era los muchos tributos, la falta de pósito, el no tener tierras propias, las cortas haciendas raíces enajenadas por ínfimos provechos a vecinos de otros pueblos, y la falta de tierra boyal. Estas explicaciones, no obstante, no eran más que presunciones, ya que no se basaban ni en hechos ni en informaciones concretas, sino en conjeturas y presunciones. Otros muchos informantes adoptarían la misma actitud, asumiendo que las razones del abandono eran tan obvias que no hacía falta explicarlas. Bastaba con referirse a ellas como las «causas generales bien sabidas para la verificación de tantos (despoblados) en esta provincia» ${ }^{42}$.

Cuando las causas del abandono eran conocidas, se hizo evidente que en la mayoría de los casos no se debían ni a la negligencia, ni a la litigiosidad de los vecinos, ni la mala voluntad de individuos, sino a mutaciones sociales, económicas y políticas de larga (y a menudo lenta) duración. Hubo despoblaciones catastróficas por peligro eminente como resultado de epidemias, la cercanía de la frontera en tiempos de guerra, o la ocupación extranjera que dejó la jurisdicción «quemada, robada y despoblada» ${ }^{43}$. Muchas otras eran progresivas, como el deseo de evadir las

40. Petición de Gabriel Bayán y consortes sobre la repoblación de Avellaneda, ANH, consejos 4047. Este caso fue estudiado en Guerrero Mayllo, 1994.

41. Informes de Francisco de la Rúa y Quiñones, alcalde mayor que fue de Talavera al fiscal Campomanes, de 20.7.1768 y de 14.7.1768 en el expediente sobre la repoblación de Avellaneda ANH, consejos 4047, fols. 18v y 20v.

42. Informe de Francisco Antonio Muñiz, abogado del Ayuntamiento de 3.1.1785, AHN, consejos 4057, exp. 16, fol. 22v. Vicente Elías, 1984, registra la persistencia, incluso a finales del siglo XX, de leyendas o tradiciones sobre dónde había pueblos y por qué se han abandonado. Se sigue, además, empleando la misma lógica que en el antiguo régimen según la cual los vestigios de casas e iglesia y el tener nombre hacen suponer que en estos lugares había habido un núcleo de población.

43. «Los lugares de los valles de Broto y Tena...» (Huesca) petición sin fecha inserta en BNE VE/200/11 y la descripción hecha por el procurador general de la villa de Hornillos en 1711, ARCHV, Pl. Civiles, Pérez Alonso (OLV) 0041/11 mencionaron enfermedades. La fe del escribano Antonio Manuel Olivaros de 8.11.1794 en el expediente titulado «Marqués

Ediciones Universidad de Salamanca / @®@@ Stud. his., H. ${ }^{a}$ mod., 42, n. 2 (2020), pp. 289-328 
contribuciones o la realización que el lugar escogido distaba de ser ideal ${ }^{44}$. A veces era insalubre o padecía inundaciones frecuentes (Gracia, 1998, p. 25; García Caballero, 1989, p. 40; Pita González, 2007, p. 102; Serra Cifre, 1983, p. 475) ${ }^{45}$. En otras, la calidad del terreno era nefasta porque solo era apto para «unas labradas separadas con recogimiento» o solo pudo albergar un único poblador ${ }^{46}$. En ocasiones, la tierra era demasiado húmeda, pero sin riego suficiente o distante tanto de los pueblos cercanos como de los caminos ${ }^{47}$. Era evidente, además, que la despoblación podría deberse a procesos naturales de reordenación y redistribución territorial o porque los vecinos tendían a concentrarse en algunas poblaciones mayores, abandonado las pequeñas, o porque los pueblos eran demasiado numerosos y cercanos unos a otros de modo que «en este país se puede decir que sobran poblaciones y se necesitan vecinos» ${ }^{48}$.

Conscientes de estas razones e incluso de que los repetidos intentos a repoblar el mismo lugar no llevaron necesariamente a otra cosa que a un repetido fracaso, algunos interlocutores concluyeron que, por más que se intentara la repoblación,

de la Isla, vecino de Cáceres pide porción de tierra...», AHN, consejos 4060, pieza 15, fol. 1r menciona la quema y abandono por la guerra. La petición de Narciso Francisco Blázquez por los sexmeros y procuradores generales de los cinco campos de Ciudad Rodrigo, AHN, consejos 4057, exp. 16, fols. 48v y 51r menciona la frontera y las guerras como motivo para la despoblación. Sobre la diversidad de las causas que podían llevarse a la despoblación vid, por ejemplo, Reglero de la Fuente, 1998, pp. 187-209, Barba Mayoral y Pérez Tabernero, 1996, pp. 213-216 y Sánchez Benito, 2013.

44. Esta era la versión de Juan López, justicia y procurador sindico común del lugar de Narros en AHN, consejos 4087 n.9. Una provisión de 3/7/1709 registra esta impresión, que muchos vasallos con la excusa de la esterilidad de los tiempos se desavecindan de los pueblos donde tenían su domicilio, en realidad para librarse de las quintas y contribuciones reales y se introducen en las ciudades, villas y lugares de crecida población donde se dedican a pedir limosna o son vagabundos. La cédula ordena a los concejos obligarles a restituir a su lugar de vecindad, mantenerse y vivir en él, y no permitirles pedir limosna: «Impresiones que el consejo mandó hacer...», AHN, Fondo contemporáneo-ministerio de Hacienda, Lib. 6549, n. 8, recuperado de http://www.mcu.es/archivos/lhe/servlets/VisorServlet.jsp?cod=032157.

45. La importancia de escoger lugares saludables se menciona por Bruno Fernández, 1769.

46. El informe de los individuos de la junta municipal de propios y arbitrios de Cáceres, 14.4.1795 en el expediente titulado «Proyecto de población de nominada villa de Balbanera en provincia Extremadura» AHN, consejos 4060, fol. 40r y el informe del sexmero, recogido en el informe de la Junta de Representantes, en el expediente titulado «Junta de representantes establecida en salamanca sobre las providencias que ha tomado para repoblar el lugar de herreros de Peña de Cabra, 1799» AHN, consejos 4084, n. 9.

47. José García Huerte, alcalde mayor de Benavente, 1.10.1817, AHN, consejos 4047, n. 14 , fol. $17 \mathrm{v}$.

48. Ídem, fol. 18r. Cabo Alonso, 1997, p. 6 y García Zarza, 1978, pp. 121-132 mencionan la opinión de contemporáneos que veían la despoblación como una cosa natural e inevitable. Vid, igualmente, Vázquez Lesmes, 1996), pp. 126-128 sobre la relación entre el problema demográfico y la despoblación y Reglero de la Fuente, 1998, pp. 214 y 217-218 sobre la idea de la reorganización y redistribución. 
«no se ha podido conseguir» por lo que no tenía sentido insistir en ella. Las malas condiciones del lugar eran tales que sería imposible redimirlo ${ }^{49}$. Después de todo, como «a las utilidades siguen la gente como la sombra al cuerpo y si hay falta de utilidad no tiene el tiempo virtud para reparar este daño» mejor abandonar los sitios que habían sido despoblados que insistir en mantenerlos o reanimarlos ${ }^{50}$. Siguiendo estos criterios, algunos interlocutores prefería apoyar a los lugares ya existentes ${ }^{51}$. Este debate fue recogido por Antonio Ponz en su viaje por España en la década de 1780. Ponz insertó un supuesto diálogo en el que preguntó a un interlocutor si no era mejor acudirse a la repoblación que a la creación de nuevos asentamientos. Este contestó que «los despoblados merecen mucha consideración... y más aquellos en donde se sabe que hubo pueblos en otros tiempos» pero insistió que era preciso preferir los lugares ya asentados porque, al contrario de los despoblados, «los pueblos ya fundados tienen a su favor una ejecutoria, y consiste en el consentimiento de muchos hombres, que los eligió, o por la fecundidad del terreno, o por lo saludable del aire, por el buen temple, por la excelencia de las aguas, vecindad de los ríos o fuentes o por otras razones. Son como las rutas, o caminos que la experiencia y el consentimiento general ha establecido: rectificarlas, alienarlas y perfeccionarlas es grande empresa. Apartarse notablemente de ellas es buscar rodeos, dificultades insuperables, y errarlo de medio a medio» (Ponz, 1780, vol. 9, pp. 239-240).

No era por tanto sorprendente que tras más de 18 años de discusión sobre si hacía falta o no repoblar del despoblado de Villar del Rey (Ciudad Rodrigo) y tras debatir sin cesar quién lo debería hacer y cómo, en 1816 algunos de los interlocutores concluyeron que la empresa no tenía sentido alguno. Muchos pueblos estaban arruinados y su socorro era mejor que reanimar un lugar que se despobló muchos años atrás, quién sabía por qué.

\section{IDENTIFICANDO EL ABANDONO}

Si una primera presunción indicaba que los despoblados tenían a priori un potencial acreditado, por lo que su reforma era posible y de provecho, una segunda apuntaba que en el debate no había solo referencias al abandono demográfico y económico, sino también al vacío jurídico y político. Las campañas de repoblación hacían constante alusión a estos factores, ante todo, a derechos y estructuras que, a pesar de la ausencia de pobladores (o de pobladores «suficientes»), no habían prescrito

49. José García Huerte, alcalde mayor de Benavente, 1.10.1817, AHN, consejos 4047 n. 14, fol. 17v. Vid., igualmente, García Caballero, 1989, p. 42.

50. Martínez de Mata, F. «Lamentos apologéticos de abusos dañosos del pueblo bien recibidos por mal entendidos» BNE Mss. 10606, fol. $21 \mathrm{r}$.

51. «Discursos políticos del marqués de Monte-Real, ministro del consejo de Castilla», sin fecha, siglo XVIII, Biblioteca del Palacio Real (en adelante BPR), II/3496. 
del todo. Por ejemplo, los despoblados seguían teniendo su propio territorio y jurisdicción. Aunque sin vecinos, el concejo de un despoblado podía seguir reuniéndose y su territorio manteniéndose mediante apeos y amojonamientos ${ }^{52}$. Los que vivían en un despoblado podían obedecer a jueces que llevaban a cabo actos jurisdiccionales, controlaban el territorio, y adjudicaban posturas para el abastecimiento local ${ }^{53}$. Estos jueces podían verificar que los vecinos de otros núcleos no aprovechaban indebidamente los recursos locales, cortando madera y usando los pastos. Podían dar permiso al tabernero que vendía vino en días festivos y embargar los bienes de unos habitantes que muy a menudo se identificaban como «vecinos». Los jueces de un despoblado también podían tener jurisdicción para castigar infracciones y crímenes y disponían de cepo y grillos ${ }^{54}$. Por ello, la jurisdicción de un despoblado no se podía usurpar por las justicias colindantes bajo la excusa de que la despoblación había convertido el territorio en jurisdicción de las autoridades más cercanas ${ }^{55}$.

La presencia de jueces en los despoblados no solo era posible, sino que a veces se consideraba necesaria. Los que vivían en un despoblado podrían reclamar su asistencia para «todos los asuntos que en él ocurran...no teniendo consideración a los muchos o pocos súbditos sino a la pronta y fácil administración de justicia» ${ }^{56}$. Esto incluso era verdad en un despoblado con una sola casa, «o mejor dicho cuadras incomodas» y con el guarda del término como único habitador porque los demás arrendatarios o dormían en otras partes o no quedaban en él más de ocho días. Este era el caso porque «la experiencia misma ha acreditado la necesidad de que resida [el juez localmente] para que no vuelva a suceder a los moradores de aquel sitio lo que ya sucedió al arrendatario Joseph Pérez que habiendo sido gravemente

52. Nombramiento despachado por Juan Antonio Ortiz, corregidor de la villa de Olmedo a favor de Juan García de Santiago, de 18.3.1675, ARCHV, Pl. Civiles, Alonso Rodríguez (F) $2226 / 3$.

53. Según ARCHV, Pl. Civiles, Alonso Rodríguez (D) 0642/2, el despoblado de Duruelo pagaba impuestos, alcabalas, derechos de cientos, servicio real, tercias, repartimiento de soldados, milicianos y derecho de fiel medidor. Sus jueces daban posturas a los abastos y hacían otras gestiones jurisdiccionales, después de haber tomado posesión de su cargo. Vid, igualmente, ARCHV, Pl. Civiles, Alonso Rodríguez (D) 0642/2. ARCHV, Pl. Civiles, Pérez Alonso (OLV) 1280/1 incluye un embargo de bienes ordenado por el alcalde ordinario de un despoblado.

54. Nombramiento despachado por el corregidor el licenciado juan Antonio Ortiz el 18.3.1675: ARCHV, Perez Alonso (F) 3225/3. ARCHV, Pl. Civiles, Pérez Alonso (OLV) 680/2 registra también la existencia de un alcalde mayor en el despoblado de la Navilla en 1792, el que obraba, al parecer, desde al menos 1783. En ARCHV, Pl. Civiles, Fernando Alonso (OLV) 0607/3 se tramita el cese de un juez de despoblado.

55. Petición de Nicolás Mata por María Antonia Fernández de Villaroel apoderada de su marido el conde de Salvatierra, Valladolid, 11.9.1792, ARCHV, Pl. Civiles, Alonso Rodríguez (D) $0642 / 2$.

56. Petición de Francisco González Calvo, arrendatario del despoblado de Salinas (Zamora) de 22.11.1787 y la discusión que sigue, ARCHV, Pl. Civiles, Alonso Rodríguez (OLV) 1019/5.

Ediciones Universidad de Salamanca / @®@@ Stud. his., H. ${ }^{a}$ mod., 42, n. 2 (2020), pp. 289-328 
herido en él, se halló sin juez que le administre justicia y el alcalde mayor no pasó a hacerlo hasta después de ocho días, aunque se le dio hasta tercer aviso» por lo que el infractor se quedó sin castigo y el crimen sin remedio y «no se vindicaron los intereses, la tranquilidad entre moradores y pasajeros y cuanto es preciso para mantener la sociedad civil regida por los jueces».

Los derechos y estructuras que sobrevivieron la despoblación no eran solo civiles sino también eclesiásticos. Un despoblado podría tener su iglesia edificada, donde se llevaban a cabo procesiones e incluso podía mantener cura propio, beneficio eclesiástico, obra pía, o un monasterio en el que se celebraba misa pública ${ }^{57}$. Los derechos económicos también perduraban. Las tierras de un despoblado podían ser cercadas y roturadas porque las mismas conservaban su condición de tierras de cultivo y no de puro pasto a pesar de haber sido abandonadas incluso 20 o 30 años atrás y haber servido desde entonces solo como dehesas ${ }^{58}$. Los despoblados conservaban su propiedad comunal, incluyendo pastos y abrevaderos que solo sus vecinos podrían usar. Por ello, el corte de madera en un despoblado sin tener derecho legítimo se podía perseguir como si fuera un delito ${ }^{59}$. A raíz del abandono, el uso de los comunales era usurpado a menudo por los pueblos colindantes que intentaban acaparar estos privilegios, que no les pertenecían e incluso pleiteaban unos con otros sobre su uso y división ${ }^{60}$. A veces, esto se hizo de forma pacífica

57. En ARCHV, Pl. Civiles, Perez Alonso (OLV) 415/1 se menciona que Miguel de Jesús María Ochoa era «cura propio» del despoblado de la villa de Castronuevo» (Ávila) donde hubo iglesia en 1768. En ARCHV, Pérez Alonso (OLV) 1247/11, se discute, por ejemplo, la presentación a un beneficio vacante en el despoblado de San Pedro de Villalonga (León) en 1776. Según ARCHV, Pl. Civiles, Pérez Alonso (OLV) 0041/3, un despoblado puede tener obra pía con cuentas y su iglesia parroquial con un beneficiado. Según ARCHV, Pl. Civiles, Alonso Rodríguez (D) 0642/2 en el despoblado de Duruelo hubo un convento de orden de carmelitas descalzas en el que se celebraba misa y se hacían procesiones. La lista de despoblados en el partido de Ciudad Rodrigo, fechada Ciudad Rodrigo, 15.12.1784, incluida en AHN, consejos 4057, exp. 16, fols. 14r-19r enumeraba múltiples despoblados que eran «cabeza de beneficio.» La vista de los fiscales del consejo, Madrid, 7.10.1781, AHN, consejos 4062, fols. 15r-23v, en fols. 17r-19r contiene amplia información sobre los despoblados con iglesia en ruina o sin ruina, con curato, beneficio, párroco, y misa.

58. ARCHV, Pl. Civiles, Pérez Alfonso (F) 0609/1.

59. ARCHV, Pleitos Criminales, Alonso de Liébana Mancedo (OLV), 0331/16 que recoge la acusación contra dos labradores de cortar árboles en el despoblado de Mazariegos (Palencia) y haberlos vendido.

60. Concejos vecinos podían litigar sobre la jurisdicción (y uso exclusivo de recursos) que cada uno de ellos pretendía tener en un despoblado cercano: ARCHV, Pl. Civiles, Alonso Rodríguez (F) 2226/3, ARCHV, Pl. Civiles, Alonso Rodríguez (D) 526/2 y ARCHV, Pl. Civiles, Pérez Alonso (F) 2638/1. En 1791, el consejo de las Villas de Blasco Millán y Gimialcón (Ávila) pidió no probar la división entre su término y el despoblado de Duruelo: ANH, consejos 4047, n. 9. Sobre la persistencia de una variedad de derechos vid, por ejemplo, Gracia, 1998, pp. 23-24. Sobre pleitos entre poblaciones colindantes sobre derechos en un despoblado

Ediciones Universidad de Salamanca / @@@ Stud. his., H. ${ }^{a}$ mod., 42, n. 2 (2020), pp. 289-328 
mediante una política que buscaba la unión entre pueblo y despoblado, extendiendo los derechos del pueblo a los pocos habitantes del despoblado con el fin de que estos harían lo mismo, otorgando a los limítrofes el goce de los privilegios de vecindad en el despoblado. En ocasiones, esta política produjo acuerdos por los que los vecinos de un despoblado se anexaban voluntariamente al pueblo limítrofe «junto con sus heredades tanto comunes como concejiles» ${ }^{61}$. En casos extremos, esta integración podía ser tan absoluta como para justificar el desmantelamiento material de las pocas viviendas que quedaban en el despoblado, la disolución de su concejo y la pérdida de su condición de lugar independiente.

Aunque estos procesos de integración, cuya frecuencia es difícil de estimar, podían transcurrir pacíficamente, a menudo provocaban confrontamientos. De esto se quejaron los últimos dos vecinos de Narros del Monte (Arévalo) quienes explicaron que muchos de sus antiguos paisanos pasaron a habitar Langa y que, ahora, con la ayuda del cura, iban desmantelando las casas e iglesia "por su propia utilidad e indebido interés» queriendo «aminorar Narros y traer a su pueblo los pocos vecinos que habían quedado para apropiarse de la jurisdicción, tierras, prados y demás emolumentos consiguientes a la despoblación de un lugar» ${ }^{62}$. Aunque los dos estaban con «ánimo de sostener su vecindad y la población» en Narros, sus rivales lograron que fuera agregado a Langa con el pretexto de que ya no tenía vecinos «en gran perjuicio de la causa común y del estado». En otras ocasiones, la ciudad en cuya jurisdicción estaban incluidos los despoblados buscaba controlar sus aprovechamientos mediante una enumeración anual de cuáles territorios lo eran y quienes podían aprovecharse de ellos (Jara Puente, 2002-2003, 94).

Si los derechos de un despoblado no prescribían, tampoco lo hacían las obligaciones. En los despoblados persistían las contribuciones ordinarias y extraordinarias correspondientes a las heredades situadas en el término, así como el alcabala y cientos sobre la venta de bienes raíces ${ }^{63}$. Los que usaban el terreno pagaban al rey

vid Ríos de Balmaseda, 2004, pp. 12-14 y Reglero de la Fuente, 1998, pp. 214-215. Algunas de estas preguntas también se barajan en Sánchez Benito, 2013, pp. 338-351.

61. Ese era el caso aparentemente en Villacastín según Martínez Moro, 1985, p. 82.

62. Representación de Manuel de Llenera y Juan López, vecinos del lugar de Narros del Monte, Ávila 16.2.1813 también recogida por el corregidor de Arévalo, AHN, consejos 4087 n. 9, 1 expediente, fol. 1r y segundo expediente, fol. 13r. Archivo General de Simancas (en adelante AGS), CRC, 126, 11 conserva una petición de Juan de San Vicente sobre el beneficio eclesiástico de Narros del Monte y Langa de 1524-1527.

63. En ARCHV, Pl. Civiles, Alonso Rodríguez (F) 2226/3 el consejo de Cisneros (Palencia) y el consejo de Pozo de Urama se confrontaron sobre sus derechos respectivos en el despoblado de Villahilar. De la discusión se hizo evidente que hubo repartimientos de servicio ordinario y extraordinario correspondiente a heredadas situadas en el término, así como alcabalas y cientos. Barba Mayoral y Pérez Tabernero, 1996, pp. 225-226 y 230 mencionan igualmente el pago de

Ediciones Universidad de Salamanca / @@@ Stud. his., H. ${ }^{a}$ mod., 42, n. 2 (2020), pp. 289-328 
lo que le era debido y lo mismo pasó con los diezmos ${ }^{64}$. Debido a esta persistencia, en 1624 la chancillería de Valladolid obligó a quienes repoblaron el despoblado de Cespedosa de Agadones (Salamanca) a pagar al convento de Sancti Spíritus de Ciudad Rodrigo los réditos de un censo perpetuo que este tenía sobre algunos bienes en el despoblado desde el día de su repoblación ${ }^{65}$. Con ello, la Chancillería desestimó la versión de la parte contraria, según la cual la despoblación convirtió a lo que una vez eran bienes censables en tierras de "pasto común» por lo que el derecho al censo cesó, por no tratarse ni de los mismos bienes, ni ser ellos sucesores de los habitantes originales. Siguiendo la misma lógica, en la década de 1750, el fiscal de la Chancillería de Valladolid opinó que los servicios de despoblados deberían recaer sobre los pueblos que utilizaban su jurisdicción porque, al gozar de sus derechos, se debían cargar también sus obligaciones. Lo contrario también era cierto: los pueblos dispuestos a cargar con obligaciones deberían de gozar de los derechos. Esto fue lo que ocurrió cuando el pueblo de Aribayos se fue abandonado poco a poco por sus vecinos, que pasaron a vivir en Casaseca de las Chanas (Zamora), quedándose en la población en 1611 una sola vecina, viuda y pobre que no podía pagar los pechos, alcabala, millones y derramas. Los de Casaseca, deseando seguir usando el territorio de Aribayos ofrecieron entonces cargarse con sus obligaciones (García Caballero, 1989 , p. 41) ${ }^{66}$. Tras llegar a un acuerdo con otro pueblo limítrofe (la Moraleja del Vino), los vecinos de ambos convinieron en usar el despoblado conjuntamente, pagando sus tributos a medias.

En todos estos casos, se admitía la persistencia legal de una estructura comunitaria en territorios de hecho cuasi o totalmente abandonados. Desde esta perspectiva, lo que más llama la atención en estos debates, no es tanto el deseo de reforma, sino cuántos despoblados mantuvieron su integridad territorial, sus derechos y obligaciones, a pesar del abandono. Lo contemporáneos eran conscientes de esta realidad y visualizaban los despoblados no tanto como espacios vacíos o yermos, sino como lugares saturados de derechos y regidos por normativas. Aunque carecían de personas (o suficientes personas), los despoblados seguían siendo «entidades de población»

alcabala en despoblados por los «vecinos encabezados.» Lo mismo hace Jara Puente, 2002-2003, pp. 92-94, aunque reduciendo la pregunta a la existencia o ausencia de vecinos contribuyentes.

64. Poder dado por los vecinos del lugar de Rasuero, 13.3.1768, en el expediente titulado «Priora y convento de S. Agustin de Nuestra Señora...pide repoblar el lugar de Astudillo» AHN, consejos 4086, fols. 96r-97v y ARCHV, Pl. Civiles, Pérez Alonso (OLV) 607/3, 1270/16, 1273/8 y 1273/12. Vid., igualmente, Reglero de la Fuente, 1998, p. 214, lo que también conlleva disputas entre abadías, beneficiados y clérigos de iglesias comarcanas sobre el cobro de diezmos en estos despoblados. Barba Mayoral y Pérez Tabernero, 1996, p. 237 también documenta el cobro de diezmos en despoblados.

65. ARCHV, Pl. Civiles, Pérez Alonso (F) 2660/1.

66. La memoria de Aribayos se perdura hasta hoy día en el municipio de la Moraleja que conserva una zona en el suroeste cuyas calles se llaman todos «Aribayos». 
es decir, eran un tipo particular de núcleo poblado, caracterizado paradójicamente de forma negativa, por no ser lo que deberían ser (García Zarza, 1978, pp. 30-35). No es por tanto sorprendente que en 1792 Manuel Bernaldo de Quirós, supuesto alcalde mayor del despoblado de Navias de Dueñas, se refería al despoblado como «villa de Navias» mientras que sus rivales insistían que en realidad se trataba de un despoblado ${ }^{67}$. Tampoco sorprende que alguien concluyera que al proceder a repoblar los despoblados, por un lado, «no son atendidos otros derechos que tenían y les correspondían en aquel mismo pueblo o termino cuando se hallaba poblado» y, por otro, no se tomaban en cuenta los que habían sido «tomados o malamente adquiridos por la despoblación» ${ }^{68}$. Es posible, por tanto, que la abundancia de despoblados en unas provincias y épocas en comparación con otras, no se deba solo, ni mayoritariamente, al desarrollo o retroceso demográfico o económico, sino a los vaivenes de la memoria social y jurídica que insistían (o no) en conservar el recuerdo de lo que una vez había existido. Donde abundaban los despoblados tal vez había habido una crisis particularmente aguda, pero también es posible que hubiera mayor dificultad en admitir la desaparición definitiva de unas entidades inexistentes, pero cuya memoria perduraba.

La repoblación de los despoblados buscaba, por tanto, no solo aumentar el número de personas y tierras labradas sino también eliminar unas comunidades fantasmas que persistían, a pesar de carecer de personas (o suficientes personas). Se trataba de estructuras políticas y legales problemáticas en las que la comunidad de derecho y de hecho no se correspondían la una con la otra. Vistas desde esta perspectiva, las campanas de repoblación tal vez tenían mucho más en común con sus antecedentes medievales de lo que habríamos imaginado. Los que habían estudiado la repoblación medieval se preguntaban desde mediados del siglo XX si ésta implicaba la instalación de personas en lugares deshabitados o si, por el contrario, consistía en la reorganización de enclaves ya existentes (García de Cortázar, 1988, pp. 17-18; Escalona Monge, 2000-1). ¿Hubo un espacio absolutamente vacío y de nadie (como algunos argumentaron) o una reorganización de tierras ya ocupadas por una población cuyas estructuras se querían modificar? ¿Se trataba de la instalación humana y del aprovechamiento mejor del territorio, o de procesos de control y reordenación? ¿De transformaciones demográficas y económicas o de la imposición de formas jurídicas y políticas? En las tierras que se querían reformar ¿Faltaban cuadros productivos o administrativos? ¿Era la repoblación medieval, en otras

67. La discusión acaecida en ARCHV, Pl. Civiles, Pérez Alonso (OLV) 680/2. Este despoblado se menciona en Martínez Díez, 2017, p. 522. Está igualmente incluido en el Nomenclátor, 1789, p.465 como parte de la jurisdicción de Olmedo (Valladolid).

68. El fiscal, Madrid, 23.10.1806 en ARCHV, Pl. Civiles, Lapuerta 2153/1, fol. 70v.

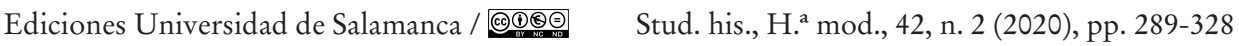


palabras, una empresa demográfica y económica o un proceso de ensanchamiento del poder que conllevaba una reforma territorial? ¿O tal vez ambas?

\section{LA FORMACIÓN DE NÚCLEOS}

Lo que posiblemente explicaba mejor la insistencia en reanimar los lugares saturados de derechos, pero sin habitantes era la convicción de que la concentración humana en núcleos legal y políticamente reconocidos era el modo ideal de gestionar tanto a las personas como el espacio: «pues con las poblaciones se logra, no solo el hacer fértiles infinitas porciones de tierras incultas, que poseídas de un monte bajo, lo hacen inútil a todo beneficio... sino también la proporción de más número de contribuyentes a su majestad en reales y personales» ${ }^{69}$. La necesidad de luchar contra tierra «que ni conoce arado, ni la habitan otras personas ni reses, que las fieras» y vencer los obstáculos que la naturaleza ha impuesto a los seres humanos, se decía, eran «la razón que los hombres se reunieron en pueblos y forma todavía una de las primeras obligaciones de toda sociedad política (Melchor de Jovellanos, 2000 , pp. 219 y 318$)^{70}$. Pocos interlocutores cuestionaban estas premisas, preguntando, por ejemplo, si no sería de mayor provecho sostener una "población rústica derramada sobre los campos» en vez de formar poblaciones. Después de todo, teniendo labradores aislados viviendo cerca de sus labranzas evitaría «el choque de pasiones que agitan a los hombres reunidos en pueblos». La lejanía de unos a otros garantiría que estén todos «distantes de aquel fermento de corrupción que el lujo infunde siempre en ellos con más o menos actividad» siendo en este caso su única distracción el trabajo.

Si el consenso parecía indicar que la formación de pueblos era la mejor manera de reformar el territorio, también incluía la conclusión de que estos pueblos tendrían que operar como republicas propiamente dichas, con sus propias autoridades y leyes. Esta era la evolución tanto normal como preferida. A esto se referían, por ejemplo, los vecinos de la villa del Arenal (Ávila) quienes pidieron en 1773 permiso para establecer una población en un sitio llamado Majadas. Explicaron que tenían tierras en aquel lugar y que, para poder labrarlas mejor, desde hacía varios años habían edificado casas y vivían continuamente en ellas. ${ }^{71}$ Estas circunstancias, así como la convicción de que el aire y la tierra eran mejores en Majadas que en Arenal

69. Pedro Manuel Sáenz de Pedroso, procurador general de los reinos, Madrid, 8.4.1767, AHN, consejos 4057, exp. 2.

70. Vid, igualmente, ARSMAP) 42/3. Sobre la importancia de poblaciones, vid, igualmente, Herzog, 2018.

71. Petición de 17 vecinos de la villa de Arenal a establecer una población en el sitio de Majadas, AHN, consejos 4047, n. 4. El Arenal era una aldea que en 1732 obtuvo el titulo de villa. Por aquel entonces tenía 120 vecinos y más de 500 habitantes: Ayto. de El renal, legajo 1,

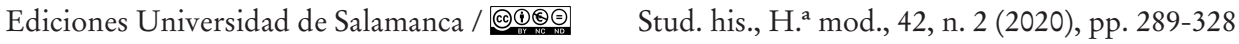


les convencieron de la necesidad de «fundar [en Majadas] un pueblo donde residir en forma civil». Pidieron por tanto señalarles tierras comunes y justicias.

$\mathrm{Si}$, inicialmente, se podría pensar que la dependencia de los núcleos nuevos respecto a los viejos era positiva porque «los pueblos cuando nacen necesitan el apoyo y ánimo de otros mayores para sostenerse e ir creciendo, lo mismo sucede con los cuerpos morales que con los físicos, de otra suerte perecen por su debilidad o por la prepotencia del más poderoso» eventualmente, se esperaba que los enclaves, una vez bien formados, llegarían a independizarse: «esto no impide que cuando éstos crecen y pueden ya manejarse por sí solos adquieren el privilegio de villazgo» ${ }^{72}$. Fue merced a ello, que en 1766, la aldea de Villaviciosa (Córdoba) pudo convertirse en villazgo y separarse de la jurisdicción de Espiel, población a la que pertenecía anteriormente ${ }^{73}$. Así, Villaviciosa, que fue fundada a principios del siglo XVIII servía como «un ejemplar práctico que demuestra la utilidad de la fundación (de poblaciones)... pues ha visto en medio siglo crecer tanto su vecindad sin más fomento que la fertilidad del terreno... y los moradores con todas las conveniencias propias de unos labradores».

Sin embargo, mientras muchos insistían por lo menos en una época de tutelaje por comunidades ya asentadas, otros argumentaban que la independencia del renovado poblado era esencial desde un primer momento porque las poblaciones del entorno tenían sus propios intereses y raramente permitían asegurar el éxito de la repoblación. O preferían que el pueblo no se creara del todo, o preferían mantenerle sujeto a su jurisdicción por temer la minoración de regalías, términos y derechos. Después de todo, «es cosa muy sabida en todos tiempos que los pueblos grandes impiden la prosperidad a los pequeños y nacientes si no se le pone al frente quien les contenga por solo el respeto del bien comunal» ${ }^{74}$. Por tanto, «los intereses y autoridad de los concejos y de los poderosos es uno de los grandes impedimentos para lograr la repoblación» ${ }^{75}$. Estos concejos y poderosos se habían «hecho dueños

folio s/n, recuperado en https://es.wikipedia.org/wiki/El_Arenal_(\%C3\%81vila). En 1751 la villa tenía 230 vecinos y en $1786,1192$.

72. El duque del infantado en el expediente con el concejo de la villa de Melgar de Fernamental, recibido el 16.12.1803, ARCHV, Pl. Civiles, Lapuerta 2153/1, fols. 65v-66r.

73. El intendente de Córdoba, el 11.12.1766, AHN, consejos 4057, exp. 2, fols. 16v-17r y 24v-25r. Según la página web de Villaviciosa de Córdoba, su asentamiento «requiere importancia como aldea a finales del siglo XVII» y es a mediados del siglo posterior que, «mediante un apeo, los pobladores adquieren la propiedad plena de las tierras que habían usurpado y puesto en cultivo de cereal y sobre todo de viñedo.» (https://www.villaviciosadecordoba.es/turismo/ historia). Se especula que la concentración humana se debía en primer lugar a la existencia de un santuario a la virgen y que entre los nuevos pobladores muchos habían sido vecinos de Espiel.

74. El fiscal, Madrid 23.10.1806, en ARCHV, Pl. Civiles, Lapuerta 2153/1, fol. 71r.

75. Informe del intendente de Extremadura, el marqués de Ustariz, Badajoz, 14.3.1775, AHN, consejos 4047, n. 8, pieza 1, fol. $6 \mathrm{v}$. 
TAMAR HERZOG

DESPOBLACIÓN Y REPOBLACIÓN EN LA ESPAÑA MODERNA: CUESTIONES PARA UN DEBATE

de los aprovechamientos de pastos como baldíos y comunes» por lo que juzgaron «por intolerable perjuicio» su repoblación» ${ }^{76}$. No se trataba de sospechas sin más. Sabemos, por ejemplo, que este tipo de oposición tuvo lugar en 1788 cuando, según la versión de las autoridades de Llerena (Badajoz), cuatro vecinos de la ciudad, con haciendas y ganado en el lugar de la Higuera, habían promovido a los pocos habitantes del despoblado, casi todos colonos, criados y dependientes de ellos, solicitar al rey el privilegio de villazgo ${ }^{77}$. Mientras el alcalde mayor de la ciudad, portavoz de estos vecinos, argumentó que la petición representaba el deseo legítimo de independizarse de unas 50 cabezas de familia que lograron fertilizar un terreno antes dominado por malezas, donde actualmente había iglesia y pila, párroco dotado, y nuevas casas, la ciudad protestó reclamando que la separación de la Higuera le perjudicaría por perder importantes terrenos de pasto común, además de que el núcleo que existía no tenía las circunstancias correspondientes a una «población social» ni vecinos que tuviesen haciendas y ganados propios por ser en su gran mayoría o colonos o jornaleros.

La oposición de las cabeceras a la renovación de núcleos en su territorio expresaba normalmente el miedo a la pérdida de terrenos comunales. Pero, en otras ocasiones, revelaba otras preocupaciones. Por ejemplo, en 1818, las autoridades de la villa de Benquerencia (Badajoz) se quejaban de que, desde hacía más de 50 años para guardary asistir a sus ganados, algunos vecinos de la villa hicieron chozas en un baldío llamado Helechal. Poco a poco, se acostumbraron a vivir en él e incluso trasladaron allí a sus familias. Al ejemplo de unos siguieron otros, por lo que al presente ya eran cerca de 60 los vecinos de Benquerencia que vivían permanentemente en Helechal. Aunque conservaban su vecindad en la villa, eran «vecinos muertos» que vivían «con absoluta independencia y libertad» en el despoblado ${ }^{78}$. Para las autoridades de Benquerencia,

76. Vista fiscal, Madrid, 25.1.1776, AHN, consejos 4047, n. 8, pieza 1, fol. 27r.

77. Petición de la ciudad de Llerena por medio de Francisco Xavier del Maso, Madrid, 26.4.1788, AGS, Gracia y Justicia 873.

78. «El ayuntamiento de Benquerencia sobre que se reúnen a ella las familias que habitan en sus respectivos caseríos en el baldío de Helechal» AHN, consejos 4047, n. 12. De las respuestas enviadas al «Interrogatorio que por orden del consejo se dio para la visita de la provincia de Extremadura por el regente y ministros de la real audiencia creada en ella» el 17.3.1791 se deduce que por aquel entonces Benquerencia tenía 150 vecinos, de los cuales 40 eran labradores, 30 ganaderos, 60 jornaleros y 16 viudas pobres. Tenía una parroquia, un corral de concejo donde se celebran los pocos ayuntamientos necesarios, pero no archivo, ni ordenanzas. Hubo una sola causa penal pendiente contra un tal Francisco Domínguez, «rustico y pobre» con siete hijos por faltar respecto a la justicia. Las calles eran muy pendientes y angostas, no había mesón, ni feria o mercado, «ni es población para lo uno ni lo otro, ni hay más comercio que el que se hace con los cortos ganados.» El lugar tenía un castillo arruinado de tiempos de moros, pero no había noticia de despoblado alguno. Las respuestas al interrogatorio se reproducen en http://librobenquerencia.blogspot.com/2007/07/vii.html.

Ediciones Universidad de Salamanca / @®@@ Stud. his., H. ${ }^{a}$ mod., 42, n. 2 (2020), pp. 289-328 
su habitación en aquel lugar era «una deserción de su domicilio de que resulta no solo la despoblación... de esta villa, sino que los demás vecinos de ella tienen que sufrir por dichos moradores los bagajes, alojamientos, embargos... y demás cargas concejiles y vecinales». En algunos casos, la repoblación incluso indicaba una clara voluntad de independizarse con el fin de cargar con menos obligaciones. Esto era lo que confesó Francisco Fernández Carbonero al proponer en 1724 repoblación de la Venta del Charco (Córdoba). Su propósito declarado era esquivar las ordenes de las justicias de la cercana villa de Montoro, quienes le impidieron el corte de árboles en el monte y le exigieron el pago de alcabala, millones y cientos y otros derechos ${ }^{79}$.

A veces la oposición a la repoblación provocó discusiones legales y políticas sobre lo que el monarca podía o no hacer. ¿Tenía facultad para obligar a los propietarios a aceptar la repoblación de sus terrenos? ¿Podía obligar a municipios a desprenderse de parte de su territorio a favor de la repoblación? Mientras quienes se oponían a estas campañas invocaban títulos y derechos antiguos, así como compromisos regios de no desmembrar el territorio o jurisdicción ni enajenarlos, los que promovían la repoblación respondían o confirmando la soberanía del rey, o argumentando que el abandono produjo la expiración de derechos. El rey, decían los que integraban el primer grupo, tenía un «poder absoluto y de supremo dominio... en todo el suelo de su monarquía» que le permitía disponer de él a beneficio de la causa publica, denegando privilegios y concediendo otros de nuevo por lo que dudar de ello sería «una blasfemia política» ${ }^{80}$. Citando las palabras de Campomanes en el pleito de la provincia de Extremadura con la Mesta, constataban que «cuando se trataba de una nueva población puede y debe disponer el soberano del derecho de propiedad». De todos modos, cualquier «argumento y obstáculo» que se podía deducir según «las leyes del derecho privado» debía «callar a vista de lo que exige el derecho público» ${ }^{81}$.

Preguntando qué tipo de derechos tenían los que dejaron el terreno abandonado y yermo, algunos respondían que «hallarse de siglos acá estas tierras en un estado infructuoso, a sus dueños pues ni han tenido ni tienen, ni pueden tener por el orden regular en ellas más utilidad, que la que pudieran figurarse en unas posesiones situadas en los espacios imaginarios» (Arriquibar, 1779, p.236). Lo mismo pasó con

79. AHN, Consejos 5943, exp. 32. La petición fue publicada por Herrera García, 2009, pp.115-119. La Venta del Charco se hallaba cerca del camino que unía Andalucía con la meseta y por tanto, un lugar cómodo para tener una hospedería, como la tuvo Francisco. La Venta ya está mencionada como lugar habitado en el Catastro de Ensenada.

80. Petición de Cayo Joseph López, vecino de la villa de Zafra en 1793 en el expediente titulado «Proyecto de población de nominada villa de Balbanera en provincia Extremadura» AHN, consejos 4060, fol. 232r y su otra petición de 1795 en el expediente titulado «Marqués de la Isla, vecino de Cáceres pide porción de tierra...», AHN, consejos 4060, pieza 15, fol. 6r.

81. Informe del intendente de Extremadura, el marqués de Ustariz, Badajoz, 6.12.1775, AHN, consejos 4047, n. 8, pieza 1, fol. 18 r. 
los derechos que los pueblos tenían. Estos eran condicionados en el sentido de que fueron otorgados a los pueblos en proporción de sus necesidades (del número de habitantes), por lo que no tenía sentido mantenerlos al mismo nivel tras la despoblación. Era ilógico que un único vecino acaparara los derechos de un pueblo entero y los utilizara en solitario sin compartirlos con otros porque, si la necesidad había cambiado también lo habría de cambiar la titularidad ${ }^{82}$. Pero tampoco tenía sentido dejar en manos de quienes no poblaban el territorio los derechos de usarlo. Según y como concluyó la audiencia de Cáceres en 1796 «si después de más de cinco siglos que el rey don Alonso noveno de León concedió a Cáceres su término para que lo cultivase, esta villa y sus aldeas no solamente lo han dejado inoperante e inculto, sino que han destruido y aniquilado su precioso arbolado; Si Cáceres se ha dejado perder las varias poblaciones, que ha habido según la tradición en la sierra de San Pedro y en lo restante de la comprensión de su término, será esperable que su actual vecindario mejore el estado del terreno... para población y dehesa? «»Por el contrario, ¿no se habrán hecho merecedoras a que se les prive de un terreno, de que han abusado en perjuicio del estado y de la felicidad de la nación?» ${ }^{83}$.

$\mathrm{Si}$, por un lado, se temía la oposición de pueblos limítrofes, por otro, se quería evitar que la repoblación de unos llevara a la despoblación de otros. Después de todo, trasladando personas de un campo a otro era una pérdida de tiempo y dinero y fácilmente podría producir la despoblación de lugares ya existentes. «Porque a nos no sería provecho que se despoblase la dicha villa y su término y se poblase la dicha aldea» ${ }^{84}$. Se advertía entonces de «la decadencia que indispensablemente experimentaría la floreciente población de Melgar, si se privase a sus vecinos de los medios de subsistencia que a costa de su sudor le han proporcionado en las tierras labrantías y el pasto de dicho despoblado» y todo esto para promover una repoblación «compuesta en el día de cuatro miserables colonos e imposibilitada en prosperar en lo sucesivo por la estrechez del término que se le pretende asignar ${ }^{85}$. Esta «nueva aparente población» perjudicaría, en fin, «en gran manera a la antigua que tanta utilidad produce al rey y al estado». Por tanto, aunque «nadie duda que la

82. Petición de Juan Garijo, vecino de Valdemora y respuesta del fiscal de 20.5.1817, en ARCHV, Pl. Civiles, Pérez Alonso (OLV) 0955/1.

83 El Acuerdo de la real audiencia de Cáceres, 17.3.1796 en el expediente titulado «Proyecto de población de nominada villa de Balbanera en provincia Extremadura» AHN, consejos 4060, fols. 77v-78r.

84. Informe de Francisco de la Rúa y Quiñones alcalde mayor que fue de Talavera 20.7.1768, AHN, consejos 4047, fol. 18r y vista fiscal, Madrid, 30.3.1767 en el expediente titulado «Priora y convento de S. Agustin de Nuestra Señora...pide repoblar el lugar de Astudillo» AHN, consejos 4086, fol. 6r.

85. Manuel Sarabia, respondiendo en nombre de la villa de Melgar de Fernamental, ARCHV, Pl. Civiles, Lapuerta 2153/1, fols. 53r-v. García Caballero, 1989, p. 42, menciona un argumento similar. 
salud pública es suprema ley, que la población es el único importante fin que debe ocupar las atenciones del gobierno, pero en la inteligencia en la aplicación de estos principios consiste la dificultad. No constituye necesariamente mayor población en mayor número de pueblos y podrá muy bien suceder que aumentándose la población la despoblación se aumenta» ${ }^{86}$. A esto se referían también en 1768 los vecinos de Rasuero (Ávila) cuando se opusieron a la repoblación del despoblado de Astudillo porque temían que esta fundación llevaría a la despoblación del suyo. Rasuero era un pequeño pueblo de 14 vecinos antes de que Astudillo fue despoblado, pero ahora mantenía 83 personas ${ }^{87}$. La solución ofrecida por el fiscal del Consejo era precisamente la sumisión: Rasuero y Astudillo compartirán el agua y pastos, pero los de Astudillo tendrán que ser sujetos a la parroquia de Rasuero ${ }^{88}$.

\section{5. ¿REFORMANDO EL TERRITORIO O REFORMANDO A LAS PERSONAS?}

La mayoría de los interlocutores parecían indicar que la repoblación era un proyecto dirigido a mejorar no solo el territorio sino también a las personas, ante todo, a los labradores pobres y a los naturales «vagos y ociosos» dándoles una «ocupación útil»y asegurando que se asentaran y tengan familias. Labradores y artesanos solteros, se argumentaba, no se casaban «por no poder mantener casa, mujer e hijos con el corto jornal que ganan o... por faltarles caudales con que armar sus talleres» ${ }^{89}$. En el reino había muchos centenares, si no millares de labradores que podían «ejercer la agricultura con adelantamiento de sus casas y familias» pero que se hallaban «sin destino y ocupación» por falta de terrenos «y, lo que es más, muchos por esto mismo dejan de casar a sus hijos en la edad regular y oportuno tiempo, de

86. Vicente Pino, diputado de Extremadura, Madrid, 27.6.1776, AHN consejos 4047, n. 8 , Pieza 1, fol. 39r.

87. Poder dado por los vecinos del lugar de Rasuero, 13.3.1768 y vista fiscal, Madrid, 11.3.1769, en el expediente titulado «Priora y convento de S. Agustin de Nuestra Señora...pide repoblar el lugar de Astudillo» AHN, consejos 4086, fols. 96r-97v y 147v-152v. Actualmente, lo que queda de Astudillo, al nord-oeste de Rasuero, es una torre: vid foto recuperado de https:// mapio.net/pic/p-4867792/ y https://cartographic.info/espana/map.php?id=135386.

88. Un arreglo similar fue mencionado en el informe de Francisco de la Rúa y Quiñones alcalde mayor que fue de Talavera 20.7.1768, AHN, consejos 4047, fol. 18r y la fe del escribano Antonio Manuel Olivaros de 8.11.1794 en el expediente titulado «Marqués de la Isla, vecino de Cáceres pide porción de tierra...", AHN, consejos 4060, fols. $2 \mathrm{r}-\mathrm{v}$ y $5 \mathrm{r}$ y pieza 15 , fol. $1 \mathrm{r}$.

89. Petición de Cayo Joseph López, vecino de la villa de Zafra en el expediente titulado «Proyecto de población de nominada villa de Balbanera en provincia Extremadura» AHN, consejos 4060, fols. 1r y 225v e informe de la Real Sociedad Matritense de Amigos del País sobre el proyecto de aumentar la población de España, Madrid, 24.10.1780, ARSMAP 37/1, fol. 1r. La misma opinión se expresa por Francisco Martínez de Mata, «Lamento apologético de abusos dañosas del pueblo bien recibidos por mal entendidos» BNE, Mss. 10606, fols. 20r-v.

Ediciones Universidad de Salamanca / @®@@ Stud. his., H. ${ }^{a}$ mod., 42, n. 2 (2020), pp. 289-328 
que resultan los daños y perjuicios al estado que dejan conocerse» ${ }^{90}$. Los hombres, alegaba Nicolás de Arriquibar en 1764, se multiplicaban «como ratones» cuando tenían los medios para subsistir ${ }^{91}$. Con la repoblación, por tanto, se garantizaría que «las partes desiertas» del reino podrían prosperar merced a la llegada de «naturales que sobran en las muy pobladas y se hallen sin fomento para ser útiles a la patria» ${ }^{92}$.

Estas imágenes, que abundaban en la literatura y las ordenes de los que promovían la repoblación, se reproducían también en las peticiones de los interesados. Por ejemplo, en 1796 Miguel Moreno de la Vara y Aguilera y otros 22 vecinos de la villa de Pozo Rubio (Toledo) argumentaron que la villa tenía unos 300 vecinos, pero su término era demasiado limitado y la mayor parte de él cultivado como propio por varios labradores hacendados ${ }^{93}$. En consecuencia, la mayoría de los vecinos quedaban o sin terrenos donde labrar o con tierras que no eran ni buenas ni suficientes para la subsistencia de ellos y de sus familias «que se van aumentando». La solución que ofrecían era establecerse en la Moraleja «cuyo sitio ha tenido en el siglo pasado moradores que cultivaban aquel termino» por lo que, según ellos, podría actualmente sostener incluso hasta cien vecinos.

Si la repoblación iba a permitir la supervivencia y reproducción de labradores y artesanos pobres, también iba a cambiar la sociedad de su entorno. Mediante la repoblación de los despoblados, individuos de poco provecho y «familias sobrantes sin abrigo, ni con tierra para cultivar, ni industria a que dedicarse, o comercio» serán reformados. Este desarrollo eximiría a todos los demás «del gravamen que hoy sufren en la manutención de tantas manos vacías pues colocadas en aquel vasto desierto serán útiles» ${ }^{94}$. Por el contrario «si se les dejase en la mísera constitución de la pobreza con que hoy viven en sus países, claro está que son muy gravosos y perjudiciales o se multiplican poco como efecto de su mendicidad o, lo que más es, suelen vivir sin ley y sin rey de que se originan los vagos no solo en nuestros reinos, sino también pasan a la escoria de los extraños, de aquí los ladrones, deserciones en los reales ejércitos porque los que se criaron sin disciplina, el yugo de ella nunca

90. Petición de Domingo Sánchez y consortes, Ciudad Rodrigo 12.11.1784, AHN, consejos 4057 , fol. $1 \mathrm{v}$.

91. Arriquibar, 1779, p. 47.

92. Informe de la Real Sociedad Matritense de Amigos del País sobre el proyecto de aumentar la población de España, Madrid, 24.10.1780, ARSMAP 37/1, fol. 1v. Vid., igualmente, Francisco Antonio de Zamora Aguilar, citando a Floridablanca, Madrid, 1.1.1779, in «papeles varios» BPR II/2512, fol. 87v.

93. Petición de Miguel Moreno de la Vara y Aguilera y otros 22 consortes, vecinos de la villa de Pozo Rubio, Aranjuez, 16.4.1796, AHN, consejos 4087, n. 15.

94. En 1784, el ayuntamiento de la ciudad de Canarias pidió facultad para fundar tres poblaciones en la banda del sur para este fin: ANH, consejos 4061, n. 13, fols. 6r-9r.

Ediciones Universidad de Salamanca / @®@@ Stud. his., H. ${ }^{a}$ mod., 42, n. 2 (2020), pp. 289-328 
pueden tolerarlo» ${ }^{95}$. Después de todo, «no admite dudas ni contestación la ventaja y utilidad de un reino bien poblado que por este medio logra sin disputa fomentar la agricultura, fabricas, artes y otras lucrosas granjerías, desterrando la mendicidad, ociosidad, vagancia con conocida ventaja... y los vasallos viven aplicados, pacíficos y contentos al paso que la despoblación acarrea todos los males contrarios» ${ }^{96}$. El problema, se argumentaba, no eran las tierras limpias y despejadas que fácilmente se pueden cultivar sino «aquellas tierras ocupadas de breñas y matas silvestres que una larga serie de tiempo ha hecho inlaborables e inútiles a los pueblos y solo sirven de abrigo a las fieras y de asilo a los bandidos». Mientras este tipo de tierras abundaban, «un reino podría formarse de solo estos desiertos espantosos y su reconquista sería más gloriosa, útil y segura, que la de países distantes» (Arriquibar, 1779, pp. 234-235).

Pero la convicción de que la reforma del territorio podría reformar a las personas tampoco era compartida por todos. En 1777, el fiscal del consejo de Castilla, por ejemplo, especificó que cualquiera no podría convertirse en colono, sino que era preciso encontrar personas «con disposición de poder arraigarse» ${ }^{97}$. El fiscal no era el único empeñado en querer identificar a las personas idóneas. Otros interlocutores también argumentaban que el verdadero problema de España no era la falta de tierras, sino la falta de personas adecuadas para labrarlas ${ }^{98}$. A esto se refería el acuerdo de la audiencia de Cáceres en 1796 cuando, a propósito de un proyecto de repoblación concluyó que «lo que sobra en Cáceres es tierra...lo que falta es industria y ejercicio de la verdadera y útil agricultura. Aquí por lo general solo se quiere las tierras para esquilmarlas con poco trabajo en un año y abandonarlas luego para labrar y sembrar otras de igual clase en el año siguiente» ${ }^{99}$. Por tanto, «los que se llaman labradores en Cáceres, la mayor parte de los cuales no lo son ni pasan de meros jornaleros o braceros». Si ellos «deseasen labrar útilmente» las tierras, podrían encontrar muchas «y aun de excelente calidad» pero a los naturales del distrito les faltaba «industria»

95. El procurador de Fernando Nestares, AHN, consejos 4047, n. 8, pieza 1, fols. 32r-v. El proyecto de Nestares fue estudiado en Sánchez Belen y Saavedra Zapater, 1994 y Pita González, 2007, pp. 108-109.

96. Petición de Manuel Rodríguez vecino de Olmedo, sexmero procurador sindico general y uno de los vocales de la junta de repoblación, Madrid, 23.11.1798 en el expediente titulado «Manuel Rodríguez sexmero y procurador sindico general tierra de Ciudad Rodrigo sobre que la junta de repoblación de ella lleve a efecto la de las dehesas o despoblado de Ituero, 1798» AHN, consejos 4061, n. 2.

97. El fiscal, Madrid, 10.4.1777, AHN, consejos 4047, n. 8, pieza 1, fol. 51r.

98. Silverio Mendiuña, procurador del marqués de Algarinejo en 1816, AHN, consejos 4061, n.15.

99. El Acuerdo de la real audiencia de Cáceres, 17.3.1796 en el expediente titulado «Proyecto de población de nominada villa de Balbanera en provincia Extremadura» AHN, consejos 4060, fols. $79 \mathrm{v}-81 \mathrm{v}$. 
y era entre ellos muy común la «holgazanería». Lo que era preciso, era encontrar personas «más aplicadas y más instruidas de las reglas de la agricultura».

El dueño de Martín Hernando tomó la misma postura en la década de 1780 cuando apuntó que los que pidieron la repoblación de la dehesa no eran «personas versadas en agricultura» sino que se hallaban «destituidas enteramente de facultades y medios para seguirla, ni hacer progresos algunos, aún en los terrenos más proporcionados, fértiles y capaces de toda fructificación» por lo que poco provecho podrían sacar de la dehesa ${ }^{100}$. Eran, al contrario, «unas personas infelices, nada aptas ni a propósito para la empresa de la población y fines a que se dirige, la que ni podrá solicitar, ni menos llevar adelante por sus cortos y ningunos medios» ${ }^{101}$. «No se podía esperar de una gente que por lo regular ha seguido la holgazanería, el que se dediquen con constancia y tesón infatigable al trabajo, ni el que hagan otra transformación ni progresos en la dehesa... que los de esquilarla y disfrutarla los primeros años, a poca fatiga, y a la esperanza sola de ser terreno descansado erial y beneficiado con las majadas de los ganados y después abandonarla, dejándola disipada, incapaz de producir y destruida su superficie». Cualquier otra pretensión sería absurda. Precisamente por no entender cómo los que pedían la repoblación pensaban ejecutarla, el dueño de Martín Hernando concluía que seguramente eran testaferros de otros, muchos más poderosos y acaudalados que ellos, cuya intención no era repoblar, sino apoderarse de su dehesa. Otra cosa sería, decía el dueño, si los que proponían la repoblación hubieran sido «colonos de su satisfacción, laboriosos, versados y endurecidos en las fatigas de la agricultura».

El dueño de Martin Hernando no era el único que dudaba de la capacidad de transformación de las personas. En 1783, Juan Morales Calderón contaba que, estando en su casa, le vinieron a ver unas 46 personas de la villa de Higuera, partido de la Serena (Badajoz), todos «pobres y con familias». Le pidieron presentar en su nombre al Consejo de Castilla una petición de repoblar un sitio llamado Venta del Botello, firmando el escrito "con señal de cruz por no saber escribir» ${ }^{102}$. Eventualmente, a la petición de los primeros se sumaron otras tantas personas, hasta el numero de 218. El

100. Francisco Antonio Miñon en nombre del Marqués de Algarinejo y Cardeñosa, AHN, consejos 4057, exp. 16, fols. 42r-43r. La preocupación sobre la paga se expresa en fol. $43 \mathrm{v}$. La posible aceptación de otro tipo de repobladores y la caracterización de los actuales como «holgazanes» $\mathrm{y}$ «nada seguros:» fol. 52r.

101. Esta versión no encontraba confirmación en el escrito del abogado del ayuntamiento de Ciudad Rodrigo y asesor de su gobernador quien apuntó, al contrario, que se trataba de labradores vecinos conocidos del arrabal de San francisco que tienen algunos pares de bueyes con ganado lanar y de cerda por lo que «no le quedaba duda» que pagaran al dueño la renta: Informe de Francisco Antonio Muñiz, abogado del Ayuntamiento de 3.1.1785, AHN, consejos 4057, exp. 16, fols. 24v-25r.

102. Escrito presentado por Juan Morales Calderón por 46 vecinos de Higuera, con fecha de 26.2.1783, en el expediente con título «Juan Morales Calderón y consortes vecinos de la villa

Ediciones Universidad de Salamanca / @@@ Stud. his., H. ${ }^{a}$ mod., 42, n. 2 (2020), pp. 289-328 
problema, sin embargo, era que, según el alcalde mayor, era «indispensable» que el consejo supiera que Juan era un escribano que había estado desterrado de su pueblo y se hallaba privado de oficio con «tanta infelicidad» que andaba mendigando ${ }^{103}$. Los demás de su grupo tenían la misma condición. Todos eran muy pobres, por lo que no tenían los medios adecuados para fundar una población tal como pedían. El concejo de la villa de Melgar de Fernamental (Burgos) alegó algo parecido en 1797 contra la repoblación de Abanades. Alegaba que los futuros vecinos eran todos «prófugos y mendigos» y que si era preciso repoblar, era mejor elegir a los vecinos del Melgar, antes que extraños y personas inútiles ${ }^{104}$. En 1817, el alcalde mayor y corregidor de Benavente se opuso a la repoblación de Cejinas por la misma razón: esta repoblación fue solicitada por artesanos que nada sabían de agricultura y cuya presencia era mejor y más útil en Benavente que en la renovada población ${ }^{105}$.

Estas cuestiones también se barajaban en 1798, cuando Cristóbal García de Cantos, vecino de la villa de Retortillo (Salamanca) cuestionó las ordenes de repoblar una dehesa perteneciente a la comunidad de religiosas de Santa Clara de Ciudad Rodrigo que él tenía arrendada ${ }^{106}$. Según alegaba Cristóbal, estas órdenes le perjudicaban y eran, además, inútiles. El terreno apenas daba abasto para tres renteros y, desde luego, no podría sustentar a seis vecinos como ordenaba la Junta de Repoblación. Además, él debería tener precedencia sobre los demás a la hora de repoblar, porque ya estaba en posesión del lugar, aprovechándolo debidamente. Cristóbal pidió la intervención del Consejo de Castilla y, así mismo, ofreció poblar la

de Higuera partido de la Serena establecer población en el sitio Venta de Botello entre villa de Higuera y Retamal que ofrecen poblar» AHN, consejo 4084, fol. 1r.

103. Informe del alcalde mayor Antonio Joseph Cortés, 19.5.1783, en el expediente con título «Juan Morales Calderón y consortes vecinos de la villa de Higuera partido de la Serena establecer población en el sitio Venta de Botello entre villa de Higuera y Retamal que ofrecen poblar» AHN, consejo 4084, fols. 12r-v.

104. Manuel Sarabia, respondiendo en nombre de la villa de Melgar de Fernamental, ARCHV, Pl. Civiles, Lapuerta 2153/1, fols. 40r-57r.

105. José García Huerte, alcalde mayor de Benavente, 1.10.1817, AHN consejos 4047, n.14. Sobre este debate vid igualmente Viñas y Mey, 1941, pp. 152-153 y 158 donde se pide que no se seleccionen los ignorantes, miserables y pobres sino los más expertos y los que entienden bien «de la labranza y de creaciones de ganados». Unas consideraciones similares se barajaban durante la repoblación del siglo 16: Tapia Garrido, 1990, vol. 13, p. 20: «ninguna buena (gente) puedo hallar porque dejar la suya en tierra llana donde fueron nacidos y criados no se puede hacer sin grandes ventajas y la gente que se sujetare a ellos son hombres que las primeras pagas que le pidieren se subirán a la sierra a ser masa salteadores que los moros».

106. Natalio Ortiz de Sanzagorta por Cristóbal García de Cantos y su oferta de repoblación recibida en el consejo en 2.11.1798 en el expediente titulado «Don Cristóbal García de Cantos, vecino Retortillo, el convento de Santa Clara de Ciudad Rodrigo y los sexmeros procurador general tierra sobre repoblación la dehesa del despoblado de castillejo de Yeltes, 1798» AHN, consejos 4061, n. 8. 
dehesa, junto con sus tres hijos de ocho, siete y tres años, a los que pidió rehabilitar como pobladores, a pesar de su minoría y corta edad. Prometió poner a cada uno de ellos en su propia casa y con ganados y utensilios como «verdaderos labradores». Por si acaso, también pretendía incluir como colonos a los «demás hijos que tenga... aunque sean hembras».

La Junta de Repoblación no estuvo de acuerdo ${ }^{107}$. Según explicó su presidente, la dehesa, que ahora servía de refugio a contrabandistas y malhechores que «infestaban los caminos» estaba poblada «antiguamente» y podía acomodar entre 6 y 8 vecinos. Por ello, en marzo de 1794 la Junta ordenó su repoblación. El convento, dueño de la dehesa, se negó a acatar la orden. La ignoró y procedió a arrendar la dehesa a Cristóbal. A este contrato de arredramiento se opusieron varios vecinos de un lugar inmediato a la dehesa (Martín del Río) por el derecho de preferencia que tenían como limítrofes, por lo que el contrato de Cristóbal fue declarado nulo. Entonces, Cristóbal se personó en la causa para conseguir que se admitiera a sus hijos y a él mismo como pobladores. La Junta consideró que su petición era una excusa para suspender la repoblación, pues era vecino de Salamanca donde tenía su casa y familia. En realidad, Cristóbal solo quería disfrutar de los pastos de la dehesa como venía haciendo desde hacía tiempo en calidad de rentero. De todos modos, era evidente que sus hijos, de tan corta edad, no podían ser auténticos pobladores, por no poder subsistir por sí solos sin la compañía de su padre.

\section{LA UTILIDAD PÚBLICA: PASTOS Y SIEMBRA}

Una vez resuelta la cuestión de si se trataba de un verdadero despoblado, al que era preciso repoblar, surgía un interrogante adicional: ¿Qué tipo de repoblación sería de mayor utilidad pública? Existía la convicción entre las élites ilustradas de que era preferible el cultivo al pastoreo, que era mejor el uso individual de la tierra que la explotación comunal y que el cultivo debía ser permanente y no transitorio (en arrendamiento de corto plazo). En consecuencia, la repoblación se orientaba casi siempre a convertir tierras de pasto en tierras de cultivo e incluía licencias para cercar dehesas, roturar baldíos de forma permanente, privatizando su uso y, eventualmente, a limitar los derechos de los ganaderos, particularmente los de la Mesta (Melón Jiménez, 1989, pp.112-119; Zabala Seguín, 1994, pp.106-166) ${ }^{108}$. Se llamaba entonces a cambiar las leyes que, según algunos contemporáneos, producían

107. Informe de la Junta de Población por mano de su presidente, Domingo Fernando Cueto, caballero de Santiago, Mariscal de campo y gobernador político y militar, 1.10.1798 en el expediente titulado «Don Cristóbal García de Cantos, vecino Retortillo, el convento de Santa Clara de Ciudad Rodrigo y los sexmeros procurador general tierra sobre repoblación la dehesa del despoblado de Castillejo de Yeltes, 1798» AHN, consejos 4061, n. 8.

108. El ejemplo que mejor escenifica esta confrontación es Mellón Jiménez, 2006.

Ediciones Universidad de Salamanca / @®@@ Stud. his., H. ${ }^{a}$ mod., 42, n. 2 (2020), pp. 289-328 
el abandono de la tierra y preferían «las ovejas a los hombres» y «las lanas que los visten, que de los granos que los alimentan» (Melchor de Jovellanos, 2000, p. 341).

Siguiendo estos criterios, en 1775 , da su parecer sobre la cuestión el intendente de Extremadura, el marqués de Ustariz, el cual se preguntaba «¿a quién importa que haya menos pasto y más frutos, para que haya más hombres? Es en esto lo que consiste la felicidad de la nación, y no en que haya más o menos lomas» ${ }^{109}$. Las leyes que «establecen el aprovechamiento común son muy malas leyes; que los usos y costumbres establecidas y sostenidas en consecuencia de ellas, son muy perjudiciales; que el aprovechamiento común es el patrimonio de poderosos, el engaño, y la ruina de los pobres; y el mayor impedimento que hay contra la agricultura y la población y por consiguiente, contra las leyes de Dios, y de la nación que claman por uno y otro».

No se trataba solo de la opinión de algunos hombres doctos. En 1796, por ejemplo, los que propusieron la repoblación del despoblado de Abanades se quejaron de que los ganaderos «son siempre los defensores de los baldíos por el inmediato interés que les resulta y esto les hace prescindir de la opulencia de la nación» ${ }^{110}$. La presunción era que «los españoles tenemos la felicidad de que nuestro fértil suelo se muestra muy agradecido al cultivo». Se pretendía incluso que «la Extremadura ha sido quien ha sentido la despoblación, cuando por la fertilidad de su suelo debía ser la más poblada del reino, la más rica, y la más fructífera» ${ }^{111}$.

Estas opiniones reflejan muy bien la convicción contemporánea, según la cual había una competencia entre ganado y cultivo, la misma que sostenía que el verdadero cultivo requería un uso prolongado, tal vez permanente, sin lo cual el estado de la agricultura no podría mejorarse. Se creía que los renteros no cultivaban las tierras debidamente "por no tener un dominio privativo sobre ellas». Lo mismo se pensaba sobre las tierras que se labraban comunalmente, porque «la mayor parte del término se aprovecha en común y por lo mismo ninguno lo mira como propio, y no es fácil que haya emulación ni desvelo en cultivarlo» ${ }^{112}$.

109. Informe del intendente de Extremadura, el marqués de Ustariz, Badajoz, 6.12.1775, AHN, consejos 4047, n. 8, pieza 1, fols. 16v y $17 \mathrm{r}$-v.

110. Juan de Homar a Pedro Varela y Ulloa, ARCHV, Pl. Civiles, Lapuerta 2153/1, fols. 10v-11r. Pita González, 2007, pp. 97-98 menciona, por ejemplo, la convicción que el pastoreo era un uso inferior al cultivo.

111 Petición de Cayo Joseph López, vecino de la villa de Zafra en 1795 en el expediente titulado «Marqués de la Isla, vecino de Cáceres pide porción de tierra...», AHN, consejos 4060, pieza 15 , fols. $2 \mathrm{r}-\mathrm{v}$.

112. El Acuerdo de la real audiencia de Cáceres, 17.3.1796 en el expediente titulado «Proyecto de población de nominada villa de Balbanera en provincia Extremadura» AHN, consejos 4060 , fols. 79v y $81 \mathrm{r}$. 
Era opinión común y principio político fundamental «que interesa mucho más al Estado que sus vasallos sean propietarios, aunque en cortas porciones, que el que pocos propietarios se absorban todo. $\mathrm{Y}$ de este principio nacieron las sabias leyes agrarias establecidas en el pueblo de Dios y en las repúblicas griegas y romana: aquella repartición digo hechas de las tierras en común en la que consistió todo su poder y riqueza y sobre todo la prodigiosa propagación de los hombres». Es, además, «indisputable que la propiedad produce al ciudadano. Aquel terreno que posee le une estrechamente a la patria. En la fecundidad que su suelo y su sudor producen, encuentra no solo el apoyo de su subsistencia, sino también la esperanza de adquirir una amable compañera, y el deseo de procurar una robusta prole heredera de su propiedad. Cuando el ciudadano que vive del trabajo diario teme la carga de los hijos y cuando no aborrezca el matrimonio, lo mira a lo menos como lazo pesado $\mathrm{y}$ fomento de su mayor miseria» ${ }^{113}$.

Se argumentaba, además, que la felicidad de pocos arrendatarios contradecía a la utilidad de muchos pobladores, incluso cuando ambos estuvieran ocupados en tareas similares. En 1798, varios vecinos del arrabal de San Francisco, extramuros de Ciudad Rodrigo, representados por Manuel Rodríguez, sexmero y procurador síndico general de la tierra, así lo alegaron. Insistían en que era preciso preferirles a ellos, antes que al arrendatario, "porque él era uno y ellos muchos» ${ }^{114}$. Lo mismo pasó en Zamora, cuyo corregidor opinaba en 1769 que era preciso dar preferencia a los vecinos colindantes antes que a un solo propietario, porque esto permitiría vivir a muchos y no a uno solo, tener «una competente porción de ganados» y labrar la tierra, pagando las contribuciones reales y redimir «la necesidad en que se hallan constituidos» (García Caballero, 1989, p. 42).

En 1785, evaluando la repoblación que tuvo lugar en 1711, en Fuente Roble de Abajo (Ciudad Rodrigo), se concluyó que lo que había pasado era «un práctico argumento contra el discurso de los ganaderos y en apoyo de las pretendidas poblaciones», porque este lugar ahora proporcionaba al mercado más reses que todos los demás del corregimiento. «Haciendo paragón de aquellos nuevos colonos con el único arrendatario que tenía antes el término, notamos se mantienen allí doce familias con desahogo, crían más ganados que el solo arrendatario y presentan en los mercados porciones considerables de granos, pavos, gallinas, pollos, cerdos y

113. Vista del fiscal Francisco Rodríguez Ledesma y Vera de 19.9.1796 en el expediente titulado «Proyecto de población de nominada villa de Balbanera en provincia Extremadura» AHN, consejos 4060, fol. 124v-135r.

114. Poder dado a Manuel Rodríguez por Juan Antonio y consortes, labradores y vecinos del arrabal de San Francisco, 5.11.1798 en el expediente titulado «Manuel Rodríguez sexmero y procurador sindico general tierra de Ciudad Rodrigo sobre que la junta de repoblación de ella lleve a efecto la de las dehesas o despoblado de Ituero, 1798» AHN, consejos 4061, n. 2.

Ediciones Universidad de Salamanca / @®@@ Stud. his., H. ${ }^{a}$ mod., 42, n. 2 (2020), pp. 289-328 
cantidad de lino que se surte el público y lo que antes no se beneficiaba ${ }^{115}$ ». Este caso probaba que «los vecinos de mediana condición labrando por sí las tierras, logran mayor producción y la cría de ganado que simultáneamente promueven en lo labrantío, recibe aumento por la superior calidad de estos pastos» ${ }^{116}$. «Los intereses que produce el pasto de un despoblado se numeran fácilmente por los ganados que mantiene, los esquilmos, y crías que dan a luz cada año, un lugar poblado con terreno en iguales circunstancia, mantiene y cría ganados al duplo con el beneficio e industria de los moradores con la paja de sus mieses, con las yerbas de sus guadañas, bien aprovechadas y con las sementijas ${ }^{117}$ que solo para este fin siembran y recogen, sacando además de esto innumerables productos, por todos ramos a favor de la monarquía» ${ }^{118}$.

Mientras que se presumía que el «haberse adhesado y destinado a pasto mucha parte de tierra labrantía» era un mal uso de «los sitios más fértiles» y de »las tierras más proporcionadas para labrar» por lo que se llegó a invertir «el orden de la naturaleza» porque estas tierras, «en lugar de servir para la manutención del hombre, sirven para pasto de los ganados trashumantes», hubo quien discutió estas conclusiones argumentando que algunas tierras simplemente no eran aptas para nada más que para el pastoreo ${ }^{119}$. Esto era lo que alegó, por ejemplo, el dueño de Martin Hernando, insistiendo que la dehesa estaba «destinada como ha estado siempre a su natural producción de pasto, única de que es capaz». La misma era totalmente «inútil para las producciones que son el objeto y fin de la agricultura y para cualquiera otra cosa que no sea el pasturaje y vaqueril, a que siempre ha estado destinado y que si se le echa el arado y se altera su destino y acostumbrada producción, no hay duda que en los primeros años por la cualidad y beneficio accidental de su envejecida y asolada superficie, descansado terreno, y calor de las majadales, podrá dar algún fruto, pero a la segunda siembra, disipadas aquellas extrínsecas cualidades, ya nada se podrá esperar ni aun con mucho cultivo, beneficio y fatiga y quedando ya ni labrantío por inútil e infructífero, ni dehesa de pasto por haberse roto y desfigurado» ${ }^{120}$.

115. Informe de Francisco Antonio Muñiz, abogado del Ayuntamiento de 3.1.1785, AHN, consejos 4057, exp. 16, fol. 25r.

116. Vista fiscal, vista en el consejo el 14.12.1784, ANH, consejos 4046, fol. 78r.

117. En Extremadura se designa con el nombre de sementijas a las hortalizas, a los productos típicos de la huerta.

118. Manuel Blanco Arroyo, el beneficiado rector de la parroquia de Manzano de Ciudad Rodrigo, al alcalde mayor y corregidor interino, 29.12.1784, AHN, consejos 4057, exp. 16, fol. $20 \mathrm{v}$.

119. Narciso Francisco Blázquez por los sexmeros y procuradores generales de los cinco campos de Ciudad Rodrigo, AHN, consejos 4057, exp. 16, fol. 48r y Petición de Cayo Joseph López, vecino de la villa de Zafra en 1795 en el expediente titulado «Marqués de la Isla, vecino de Cáceres pide porción de tierra...», AHN, consejos 4060, pieza 15, fols. 3v y 4v.

120. Francisco Antonio Miñon, en nombre del Marqués de Algarinejo y Cardeñosa, AHN, consejos 4057, exp. 16, fols. 42r-53v, 48v-49r y 50r-50v. 


\section{UNA TORMENTA PERFECTA}

La complejidad de las cuestiones planteadas y el grado de hostilidad que pudieron provocar se puso de manifiesto, por ejemplo, en 1793, cuando Cayo Joseph López, vecino de la villa de Zafra, propuso fundar una población en un sitio que había sido poblado «en lo antiguo» en la sierra de San Pedro, jurisdicción de Cáceres. Su petición topó con la oposición de varios vecinos que pidieron al corregidor cederles a ellos el uso del terreno y que mientras esperaban la resolución del caso, se introdujeron en el mismo, talaron árboles y quemando la vegetación. Después ofrecieron al Rey un donativo a cambio de parar la repoblación e incluso presentaron su propio proyecto que era, según su versión, de mayor provecho ${ }^{121}$.

Según Cayo, lo que sus rivales ofrecían no era una repoblación propiamente dicha, sino la residencia de varios vecinos de la villa en el despoblado, formando «varios cortijos o casas de labor dispersas en lo más florido del terreno». Ridiculizando con ironía la oferta, Cayo la tituló de «excelente» porque era «muy generosa» al querer «costear estas obras de propia y particular utilidad con los caudales públicos».

La respuesta de la parte contraria explicó que tampoco Cayo iba a fundar una población. Lo único que quería era adquirir la posesión de unos terrenos ajenos, pertenecientes a los comunales de la entonces villa de Cáceres «aparentando la autoridad de poblar, bienhechor a la humanidad, propio al próximo, redentor de la agricultura, fomentador y conservador de plantíos, cuando por el contrario su interés y codicia es la que le ha conducido a proyectar el establecimiento de una población en termino de Cáceres con grandes perjuicios a sus vecinos» ${ }^{122}$. Invocando la posible ruina de las poblaciones ya existentes, estas personas se preguntaban: « Cómo ha de ser ventajoso para Cáceres, para Extremadura, para España, trasplantar por decirlo así, 18 individuos, sin vocación acaso de poblar aminando a 10.000 ganaderos de toda clase...»? Aun suponiéndolo útil ¿¿Será ventajoso alguna vez lo que es injusto? ¿Y no sería ofender la justicia y los respetables derechos de la propiedad, despojar a 10.000 padres de familia, a 50.000 individuos de ellas y a su posteridad de un terreno cuyo dominio y aprovechamiento común le pertenece para engrandecer a don Cayo? ...» Después de todo, «el bien común... es inasequible reuniendo en unas manos solas las fortunas de muchos individuos y si tal vez en diversas épocas

121. Petición de Cayo Joseph López, vecino de la villa de Zafra en 1793 en el expediente titulado «Proyecto de población de nominada villa de Balbanera en provincia Extremadura» AHN, consejos 4060, fols. 224r, 234v y 240r. Este proyecto se menciona brevemente en Pita González, 2007, p. 107.

122. La villa de Cáceres en 31.5.1800 en el expediente titulado «Proyecto de población de nominada villa de Balbanera en provincia Extremadura» AHN, consejos 4060, sin foliación. Vid, igualmente, el procurador del marqués de Algarinejo Silvio Mendiuña en AHN, consejos 4061, n. 15, sin foliación. 
TAMAR HERZOG

DESPOBLACIÓN Y REPOBLACIÓN EN LA ESPAÑA MODERNA: CUESTIONES PARA UN DEBATE

a pesar de esta verdad se han hecho mercedes o concesiones de dilatados terrenos, si se ha verificado la acumulación de bienes y riquezas, preciso y triste origen de la miseria de los delitos de la multitud se han juzgado necesarias para recompensar las ventajas y excesivamente mayores utilidades que produjeron a la nación los elevados servicios y trabajo de los agraciados» lo que no se verificaba en el caso de Cayo, cuyo único interés es la «negociación mercantil y ventajosa».

\section{EPÍLOGO: LA DESPOBLACIÓN DESDE UNA PERSPECTIVA ACTUAL}

Aunque muchos de estos debates parecen pertenecer a un pasado lejano, como lo son los despoblados, no obstante, algo de actualidad retienen. La siguiente historia lo demuestra. En 2010, hubo un asesinato en la aldea gallega de Santoalla do Monte (Ourense). Tras varios años sin que la investigación progresara, en 2014 se descubrió que el homicida era el hijo de la única familia originaria que residía en la aldea, que por entonces era prácticamente un despoblado, con unas 30 o 50 casas totalmente abandonadas ${ }^{123}$. El conflicto, que llevó primero a una larga serie de agresiones y, posteriormente, al asesinato, versaba sobre la pretensión de la víctima, que se mudó al pueblo trece años antes, en 1996 o 1997, de usar el monte que pertenecía a los comunes de la aldea que esta familia acostumbraba a monopolizar. La familia lo consideraba propio porque era nativa del pueblo y porque durante muchos años sus

123. Esta narrativa construye los hechos basándose en las noticias que salieron publicadas en el periódico «El País» todas salvo una de autoría de Silvia R. Pontevedra y con fechas de 3.6.2013, 4.6.2013, 17.6.2018, 14.3.2014, 21.6.2014, 28.6.2014, 1.7.2014, 29.11.2014, 30.11.2014, 2.12.2014, 3.12.2014, 14.12.2014, 16.12.2014, 2.1.2015, 18.6.2018, 19.6.2018, 20.6.2018, 22.6.2018 y 25.6.2018 y de Elisa Lois el 6.7.2018. El fiscal se refirió a los comunes del despoblado como "comunidad de montes vecinales en mano común»: reportaje de 17.6.2018. El derecho a usar los comunes se basaba en la Ley de monte vecinal en mano común de Galicia que dictaba según la reportera de El País que el requisito para gozar estos derechos era tener una «casa abierta con humo» durante 10 meses al año y una antigüedad de por lo menos un año como residente en la población: reportaje de 25.6.2018. La ley, sin embargo, indica que el requisito es ser «vecino titular de unidades económicas, con casa abierta y residencia habitual en las entidades de población a las que tradicionalmente hubiesen estado adscritos» estos montes: articulo 3. La comunidad vecinal es la compuesta por los vecinos que la integran en cada momento. La ley 13/1989 de monte vecinal en mano común de Galicia recuperado de https://www.boe.es/ buscar/pdf/1990/BOE-A-1990-3358-consolidado.pdf. Según el artículo 103.1 del «Reglamento de bienes de las entidades locales» están incluidos específicamente en el goce incluso «los extranjeros domiciliados en el término municipal» ya que se trata de un derecho ligado a la vecindad y no a la naturaleza: Raposo Arceo, J.J. (1996). Régimen jurídico de los montes vecinales en mano común en el marco de la propiedad forestal. (Tesis doctoral), pp. 30-31, recuperado de https:// ruc.udc.es/dspace/bitstream/handle/2183/13875/RaposoArceo_JuanJesus_TD_1996_01de2. pdf? sequence $=1 \&$ isAllowed $=y$.

Ediciones Universidad de Salamanca / @®@@ Stud. his., H. ${ }^{a}$ mod., 42, n. 2 (2020), pp. 289-328 
miembros habían sido los únicos residentes. Los tribunales dieron al nuevo vecino la razón. Según una sentencia dictada en 2008 por el juzgado de O Barco de Valdeorras y confirmado en 2009 por la audiencia de Ourense, el monte pertenecía a todos los que vivían en la aldea por partes iguales, los cuales deberían de reconocerse como «comuneros» (es decir, vecinos).

Las consecuencias económicas de esta decisión eran importantes porque, aparte del uso del monte para pastoreo, suponía compartir los réditos de la venta de madera -contados en varias decenas de miles de euros anuales- y la posibilidad de hacer lo mismo con lo que prometió una empresa eólica que iba a instalar 18 molinos en la jurisdicción, lo que se sumaría a un ingreso adicional de unos 12.000 euros anuales. El conflicto tardó en surgir porque los nuevos pobladores tardaron mucho en darse cuenta de sus derechos y en exigirlos hasta que finalmente el enfrentamiento desembocó en confrontación extrema y homicidio.

La convicción de la familia, que durante años residió solitaria en el despoblado, era que el territorio y la jurisdicción eran propios suyos, venía de muy lejos. Se contaba, por ejemplo, que sus miembros habían amenazado a algunos cazadores que habían comprado una cabaña en el lugar y que por miedo a represalias no habían querido volver. Curiosamente, tanto antes como después de estos sucesos, la aldea seguía funcionando como una verdadera entidad de población independiente. A pesar de haber sido abandonada por la mayoría de los residentes y albergar a una sola familia, su cabeza ejercía como presidente de la comunidad, uno de los hijos como secretario y el otro como tesorero. Tras el asesinato del nuevo vecino y el fallecimiento del pater familias de la familia originaria, el hijo mayor de éste y la viuda de aquél desempeñaron los cargos de presidencia, secretaría y tesorería. No sabemos si se reunieron en concejo alguna vez, pero sí sabemos que el asesino fue declarado culpable en 2018, tras un juicio con mucha tensión y escándalo, pero en el que las referencias históricas brillaron por su ausencia.

\section{BIBLIOGRAFÍA}

Arriquibar, N. de (1779). Recreación política. Reflexiones sobre el amigo de los hombres en su tratado de población considerando con respecto de nuestros intereses. Vitoria: Tomás Robles y Navarro.

Barba Mayoral I. y Pérez Tabernero, E. (1996). Estudio de los despoblados en el señorío de Mombeltrán. Cuadernos abulenses 25, 211-245.

Bruno Fernández, F. (1769). Instrucciones para el bien público y aumento de las poblaciones. Madrid: Viuda de Manuel Fernández.

Cabo Alonso, A. (1997). Repoblación y colonización en Castilla y León. Investigaciones geográficas $17,5-35$.

Cabrillana, N. (1971). «Los despoblados en Castilla la Vieja. Hispania, 31(119), 485-550.

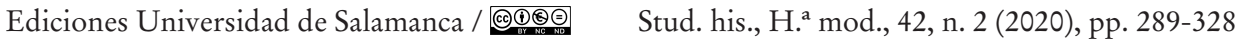


Diago Hernando, M. (1991). Los términos despoblados en las comunidades de villa y tierra del sistema ibérico castellano a finales de la edad media. Hispania, 51(178), 467-515.

Escalona Monge, J. (2000). Comunidades, territorios y poder condal en la Castilla del Duero en el siglo X. Studia historica. Historia Medieval, 18(19), 85-120. .

Forteza, P de. (1983). Yermos y despoblados; Problemas de terminología. En Estudios en homenaje a don Claudio Sánchez Albornoz en sus 90 años (vol. 3, pp. 73-85). Buenos Aires: Instituto de Historia de España.

Gracia, H. R. de. (1988). Repoblación en los Montes de Toledo durante el siglo XVIII: el caso de Jumela. Revista de estudios monteños, 82, 22-28.

García Caballero, A. (1989). La repoblación de despoblados en la provincia de Zamora en el siglo XVIII. Studia zamorensia 10, 37-48.

García de Cortázar. J.A. (1988). La repoblación del valle del Duero en el siglo IX: del yermo estratégico a la organización social del espacio. En Actas del coloquio de la $v$ asamblea general de la Sociedad Española de Estudios Medievales (pp. 15-39). Zaragoza: Diputación general de Aragón.

García Zarza, E. (1978). Los despoblados-debesas-salamantinos en el siglo XVIII. Salamanca: Centro de Estudios Salamantinos - CSIC.

González, T. (1829). Censo de población de las provincias y partidos de la corona de Castilla en el siglo XVI. Madrid: Imprenta Real.

Guerrero Mayllo, A. (1994). Una nueva población en el arzobispado de Toledo: El caso de Avellaneda en el Valle del Ibor. Espacio, tiempo y forma. Historia moderna, 7, 297-306.

Gutiérrez de Vega, F. (1781). Los enredos de un lugar o historia de los prodigios y hazañas del célebre abogado de Conchuela, el licenciado Tarngo. Madrid: Manuel Martín.

Heras Santos, J. L. de las. (2016). Cartografía de la administración de justicia en la antigua provincia de Salamanca en el siglo XVIII: la importancia de la justicia pedánea como expresión de la justicia rural en la edad moderna. En E. Jarque Martínez (coord.), El concejo en la edad moderna. Poder y gestión de un mundo en pequeño (pp.171-202). Zaragoza: Universidad de Zaragoza.

Herrera, T. de. (1652). Historia del convento de San Agustín de Salamanca. Madrid: Gregorio Rodríguez.

Herrera García, A. (2009). Una propuesta de repoblación en Sierra Morena cordobesa anterior a la empresa de Olavide. Boletín de la Real Academia de Córdoba, de Ciencias, Bellas Letras y Nobles Artes, 156, 111-119.

Herzog, T. (2010). Reconquista y repoblación: modelos ibéricos, realidades americanas y respuestas peninsulares (siglos XI-XVIII). En A. Dubet y J. J. Ruiz Ibáñez (eds.), Las monarquías española y francesa (siglos XVI-XVIII). ¿Dos modelos políticos? (pp. 45-55). Madrid: Casa de Velázquez.

Herzog, T. (2018). Indigenous Reducciones and Spanish Resettlement: Placing Colonial and European History in Dialogue. Ler história, 72, 9-30.

Jara Fuente, J.A. (2002-2003). 'Que memoria de onbre non es en contrario'. Usurpación de tierras y manipulación del pasado en la Castilla Urbana del siglo XV. Studia historica: Historia medieval, 20-21, 73-104. 
Martínez Díez, G. (2017). Las comunidades de villa y tierra de la Extremadura castellana (estudio histórico-geográfico). Valladolid: Maxtor.

Martínez Moro, J. (1985). La tierra en la comunidad de Segovia. Un proyecto señorial urbano (1088-1500). Valladolid: Universidad de Valladolid.

Melchor de Jovellanos, G. (2000). Informe de la Sociedad Económica de Madrid al Real y Supremo Consejo de Castilla en el Expediente de la Ley Agraria, 1795. En V. Llombart (ed.). Melchor de Jovellanos, escritos económicos (pp. 185-359). Madrid: Real Academia de Ciencias Morales y Políticas.

Melón Jiménez, M. A. (1989). Extremadura en el antiguo régimen. Economía y sociedad en tierras de Cáceres, 1700-1814. Mérida: Editora Regional de Extremadura.

Melón Jiménez, M. A. (introd.). (2006). Memorial ajustado del expediente de Concordia que trata el honorable concejo de la mesta con la diputación general del reino y provincia de Extremadura ante el ilustrado señor conde de Campomanes del consejo y Cámara de S.M. su primer fiscal y presidente del mismo honrado concejo, 1783. Cáceres: Caja de Extremadura.

Monsalvo Antón, J. M. (1988). El sistema político concejil. El ejemplo del señorío medieval de Alba de Tormes y su concejo de villa y tierra. Salamanca: Universidad de Salamanca.

Nomenclátor o diccionario de las ciudades, villas, lugares... y despoblados de España... formado por las relaciones originales de los intendentes... a quienes se pidieron de orden de su majestad, 22.3.1785 (1789). Madrid: Imprenta Real.

Oliveras Samitier, J. (1983). Nuevas poblaciones en la España de la ilustración (Tesis doctoral). Universidad Politécnica de Barcelona.

Pita González, M. S. (2007). Encinas del Príncipe, Villarreal de San Carlos, Valbanera y la Roza de la Pijotilla: cuatro propuestas para la repoblación de Extremadura en el siglo XVIII. Norba-Arte, 27, 93-109.

Ponz, A. (1780). Viaje por España. Madrid: Joachin Ibarra.

Reglero de la Fuente, C. (1998). Los despoblados bajomedievales en los Montes de Torozos: jerarquización del poblamiento y coyuntura económica. Edad media. Revista de historia, 1, 183-218.

Ríos de Balmaseda, A. (2004), Hontalba, un despoblado de los Montes de Toledo». Revista de estudios monteños, 106, 10-14.

Rodríguez-Moñino Soriano, R. (1998). Las nuevas poblaciones (y repoblación de sitios y lugares) durante el siglo XVIII e inicios del XIX en los fondos documentales del Archivo Histórico Nacional. Boletín de la Real Academia de Córdoba de Ciencias, Bellas Letras y Nobles Artes, 76(135), 269-286.

Sánchez Belen, J. A. y Saavedra Zapater, J. C. (1994). Un expediente de nueva población en Extremadura: el proyecto de D. Fernando Nestares (1774). En Las nuevas poblaciones de España y América. Actas del V congreso histórico sobre nuevas poblaciones (pp. 499-519). Córdoba: Junta de Andalucía.

Sánchez Benito, J. M. (2013). Términos despoblados en la tierra de Cuenca: Un problema de organización del territorio y articulación social en el siglo XV. HID 40, 327-359.

Serra Cifre, F. M. (1983). La despoblació d'Alcúdia i problemàtica de repoblació (s. XVIIIprimera meitat del XIX). Bolleti de la Societat Arqueológica Luliana, 39, 71-480.

Ediciones Universidad de Salamanca / @®@@ Stud. his., H. ${ }^{a}$ mod., 42, n. 2 (2020), pp. 289-328 
TAMAR HERZOG

DESPOBLACIÓN Y REPOBLACIÓN EN LA ESPAÑA MODERNA:

CUESTIONES PARA UN DEBATE

Tapia Garrido, J. A. (1990). Historia general de Almería y su provincia. Almería: Confederación Española de Cajas de Ahorro.

Vázquez Lesmes, R. (1996). Otras 'nuevas poblaciones'. Boletín de la Real Academia de Córdoba de Ciencias, Bellas Letras y Nobles Artes, 130, 125-141.

Vicente Elías, L. (1984). Los despoblados riojanos a la luz de la tradición oral. Cuadernos de investigación. Historia, 10(1), 243-253.

Viñas y Mey, C. (1941). El problema de la tierra en la España de los siglos XVI-XVII. Madrid: CSIC.

Zabala Seguín, A. (1994). Aldeas y campesinos en la Navarra prepirenaica (1550-1817). Pamplona: Gobierno de Navarra.

Ediciones Universidad de Salamanca / 요 Stud. his., H. ${ }^{a}$ mod., 42, n. 2 (2020), pp. 289-328 